\title{
Compatibility of Ammonia with Candidate Dry Cooling System Materials
}

April 1976

Prepared for the Energy Research and Development Administration under Contract E(45-1):1830 


\section{DISCLAIMER}

This report was prepared as an account of work sponsored by an agency of the United States Government. Neither the United States Government nor any agency Thereof, nor any of their employees, makes any warranty, express or implied, or assumes any legal liability or responsibility for the accuracy, completeness, or usefulness of any information, apparatus, product, or process disclosed, or represents that its use would not infringe privately owned rights. Reference herein to any specific commercial product, process, or service by trade name, trademark, manufacturer, or otherwise does not necessarily constitute or imply its endorsement, recommendation, or favoring by the United States Government or any agency thereof. The views and opinions of authors expressed herein do not necessarily state or reflect those of the United States Government or any agency thereof. 


\section{DISCLAIMER}

Portions of this document may be illegible in electronic image products. Images are produced from the best available original document. 


\title{
NOTICE
}

This report was prepared as an account of work sponsored by the United States Covernment. Neither the United States nor the Energy Research and Development Administration, nor any of their employees, nor any of their contractors, subcontractors, or their employees, makes any warranty, express or implied, or assumes any legal liability or responsibility for the accuracy, completeness or usefulness of any imformation, apparatus, product or process disclosed, or represents that its use would not infringe privately owned rights.

PACIFIC NORTHWEST LABORATORY

nperatert hy

BATTELLE

for the

ENERCY RESEARCH AND DEVELOPMENT ADMINISTRATION

Under Contract $E(45-1)-7830$

\author{
Printed in the United States of America \\ Available from \\ National Technical Information Service \\ U.S. Department of Commerce \\ 5285 Port Royal Road \\ Springfield, Virginia 2.2151 \\ Price: Printed Copy $\$ 5.30$; Microfiche $\$ 2.25$
}




\section{COMPATIBILITY OF AMMONIA}

WITH

CANDIDATE DRY COOLING SYSTEM MATERIALS

by

David R. Pratt

April 1976

Battelle

Pacific Northwest Laboratories

Richland, Washington 99352 
TABLE OF CONTENTS

LIST OF TABLES ............................. $i$. .

LIST OF FIGURES .................... . . .

1. INTRODUCTION ........................... 1

2. SUMMARY AND CONCLUSIONS ................ 3

3. DESCRIPTION OF THE SYSTEM .................. 4

4. CORROSION BEHAVIOR OF CANDIDATE MATERIALS .......... 4

4.1 Aluminum and Aluminum Alloys . . . . . . . . . . . . . . 9

4.1.1 Corrosion of Aluminum in Anhydrous Ammonia and Concentrated Ammonia Solutions .......... 9

4.1.2 Corrosion of Aluminum in Dilute Ammonia Solutions . . 13

4.1.3 Galvanic Attack of Aluminum . . . . . . . . . . 17

4.1.4 Use of Aluminum in DCT Ammonia Cycles . . . . . . 17

4.2 Iron-Base Alloys. . . . . . . . . . . . . . 19

4.2.1 General Corrosion Behavior of Iron-Base Alloys in Liquid Ammonia ............... 19

4.2.2 General Service Experience and Corrosion Behavior of Carbon Steel .......... . 19

4.2.3 Stress-Corrosion Cracking of Carbion Steels . . . . . 22

4.2.3.1 Causes and Inhibition.......... 24

4.2.3.2 Mechanism of Cracking and Inhibition ... . 34

4.2.4 Corrosion Behavior of Stainless Stee1. . . . . . . 35

4.2.5 Use of Iron-Base Alloys in DCT Ammonia Cycles . . . 35

5. EFFECT OF AMMONIA LEAKAGE ON CONTROL OF CONDENSATE CHEMISTRY . . . 37

6. ACKNOWLEDGEMENTS . . . . . . . . . . . . . . . . . 41

7. APPENDICES .......................... 42

7.1 Design Parameters of Industrial Equipment Handling Ammonia. . 42

7.2 Derivation of Formula Relating Solution $\mathrm{pH}$ to Ammonia

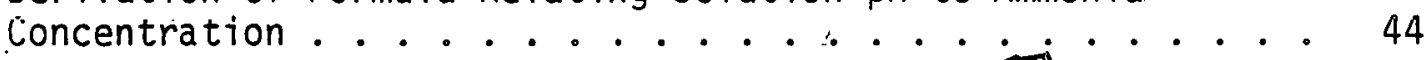

8. REFERENCES .......................... 45 


\section{LIST OF TABLES}

No. Tit.le

Page

1. Materials Resistant to Corrosion in Liquid and Gaseous

Anhydrous Ammonia... . . . . . . . . . . . . . . 8

2. Recent Materials Costs ................ . 9

3. Corrosion of Aluminum Alloys 1100 and 3003 in Unrefreshed 0.85\% Ammonia Solution ............... . 16

4. General Corrosion Performance of Various Materials in Liquid Ammonia..................... 20

5. Steels Tested in Initial Phase of AAI Research Committee Program . . . . . . . . . . . . . . . . . . 22

6. Effect of Specimen Condition and Stress Level on Stress-Corrosion Cracking of Tuning-Fork Specimens in Agricultural Ammonia . . . 23

7. Effects of Air and Water Additions on Stress-Corrosion Cracking of High-Strength Steels in Refrigeration-Grade Ammonia . . . . 25

8. Stress-Corrosion Test Data on A-517 Grade F Steel . . . . . . 30

9. Suitable Steels for Various Components in the DCT Ammonia Loop. 37 


\section{LIST OF FIGURES}

No. Title $\quad$ Page

1. Cost of Electricity as a Function of Fuel cost in 1000 MWE Power Plants.................. 2 2

2. Simplified Schematic of Power Plant Ammonia Heat Rejection System .................. 5

3. Relationship of Turbine Backpressure to Saturated Steam Temperature ................ 6

4. Dependence of Boiling Point of Ammonia on Pressure . . . . . 7

5. Corrosion of Aluminum Alloy 1100 in $80 \%, 90 \%$, and $100 \%$ Ammonia 11

6. Total Weight Loss and Initial Corrosion Rates of Aluminum Alloy 1100 as a Function of Ammonia Concentration in Water . . 12

7. Initial Corrosion Rates of Aluminum Alloys 1100 and 3003 as a Function of $\mathrm{pH}$ Controlled by Ammonia . . . . . . . . . 15

8. Corrosion of Aluminum Alloy 1100 Samples in Unrefreshed $0.85 \%$ Ammonia Solution ................ . . 15

9. Galvanic Series of Various Metals and Alloys in Liquid Ammonia 18

10. Frequency of Stress-Corrosion Cracking of Steel in Ammonia Without Added Water . . . . . . . . . . . . 26

11. The Influence of Water Content on the Stress-Corrosion Cracking Susceptibility of A-517 Grade F Steel in AirContaminated Liquid Ammonia. . . . . . . . . . . . 29

12. Schematic Polarization Curves Illustrating Effect of $\mathrm{O}_{2} / \mathrm{H}_{2} \mathrm{O}$ Equilibrium Potential on Corrosion Potential .... . ? . 31

13. The Influence of Applied Current on the Stress-Corrosion Cracking Susceptibility of A-517 Grade F Steel in AirContaminated Liquid Ammonia. . . . . . . . . . .....

14. Proposed Mechanism of Stress-Corrosion Cracking of Steel in Anhydrous Ammonia Contaminated with 0xygen and Nitrogen . . . 34

15. Condensate $\mathrm{pH}$ as a Function of Ammonia Leak Rate at Various Condensate Flow Rates, Assuming Complete Mixing . . . . . . 


\section{COMPATIBILITY OF AMMONIA}

WITH CANDIDATE DRY COOLING SYSTEM MATERIALS

\section{INTRODUCTION}

Preliminary studies conducted by the Franklin Research Institute have shown some economic advantage in the use of ammonia as an intermediate heat transfer fluid in an advanced dry cooling system concept. Figure 1 shows a comparison of the cost of generating electricity, as a function of fuel cost, for 1000 MWe plants using the indirect dry cooling system, the steam/ammonia binary cycle, the ammonia heat rejection system, the evaporative cooling system, and the "once-through" cooling system. Of the three concepts which use dry cooling towers, both the binary cycle concept and the ammonia heat rejection concept show lower costs than the conventional dry system. Of particular significance is the fact that, for fuel costs greater than about $\$ 0.20 / 10^{6} \mathrm{Btu}$, the cost of electricity is less for steam turbines using ammonia in the heat rejection system than for the binary-cycle power plants.

The initial conclusion of the work at Pacific Northwest Laboratory (PNL) concerning the use of ammonia as an intermediate fluid is that, compared with other dry cooling tower designs, potential savings may result from the lower total air-side surface area, lower cost of piping between the plant and cooling tower due to reduced duct sizes, and possibly lower material costs. Operational advantages include the ability of the system to use a conventional low back pressure steam turbine, the elimination of freezing problems, and the capability for more efficient use of augmented cooling.

Major questions which must be resolved with regard to the use of ammonia as a heat transfer fluid include the following:

- Will the ammonia cooling cycle enhance or degrade overall plant reliability? 
- Will the life of the dry cooling tower and major components in contact with ammonia equal 30 years or more?

The purpose of this report is to evaluate the materials which may be used for the dry cooling tower components in an attempt to answer these questions.

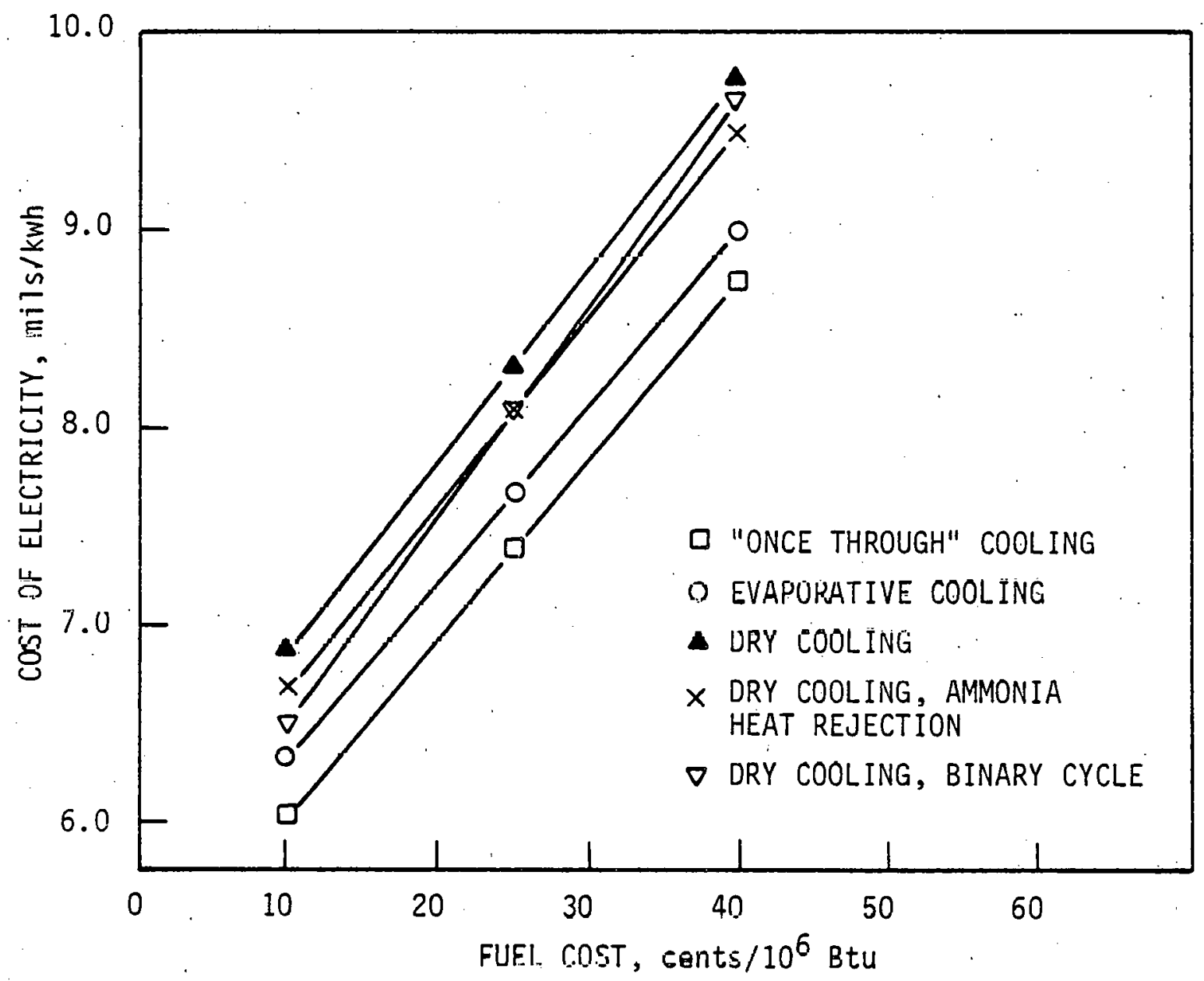

Figure 1. Cost of Electricity as a Function of Fuel cost in 1000 MWe Power Plants. (1) 


\section{SUMMARY AND CONCLUSIONS}

Candidate materials for use in the cooling cycle of a power plant ammonia heat rejection system are aluminum, carbon steel and stainless steel. Other materials are rejected as candidates on the basis of incompatibility with ammonia (e.g., copper-base alloys) or high cost (e.g., nickel-base alloys).

Corrosion of aluminum alloys 1100 and 3003 is negligible in anhydrous ammonia. Aluminum is susceptible to impingement attack by saturated, high-velocity steam; if aluminum is used in the condenser-reboiler, the first several rows of tubes must be either constructed of stainless steel or protected with stainless steel sleeves. Leakages of ammonia into the steam condensate resulting from aluminum wastage by steam impingement could result in accelerated corrosion of the aluminum tubes from the steam condensate side, since aluminum is susceptible to corrosive attack by dilute ammonia solutions. Aluminum is also susceptible to accelerated attack in air-contaminated ammonia when it is coupled with steel. This galvanic attack is inhibited if the ammonia contains 0.2 $0.5 \%$ water.

Carbon steel is susceptible to stress-corrosion cracking in aircontaminated ammonia; susceptibility is proportional to the yield strength of the steel. Cracking is caused by levels of oxygen and nitrogen as low as 1 - 2. ppm. Water added to a concentration of 0.1 $0.2 \%$ is effective in inhibiting stress-corrosion cracking of susceptibie steels in air-contaminated ammonia. Water added to liquid ammonia may be effective in inhibiting stress-corrosion cracking of steel in contact with the vapor phase. Stainless steels of all types are resistant to corrosion in liquid and gaseous ammonia.

Leakages of ammonia through the condenser-reboiler should not have an adverse effect on condensate chemistry. In fossil-fuel plants and pressurized-water reactors, leaks of ammonia into the conderisate can be easily detected and will not cause accelerated corrosion of materials in the condensate/feedwater cycle. In boiling-water reactors, ammonia is 
rapidiy decomposed radiolytically; the only problem caused by an ammonia leak would be an increased volume of noncondensable gases $\left(\mathrm{H}_{2}\right.$ and $\left.\mathrm{N}_{2}\right)$ in the condenser.

\section{DESCRIPTION OF THE SYSTEM}

A simplified schematic of the ammonia-cooled system is shown in Figure 2. Exhaust steam from the turbine is condensed on the she11side of a condenser-reboiler; ammonia on the tube side is vaporized. The ammonia vapor is then carried to the air-cooled heat exchanger where it is condensed and returned to the condenser-reboiler. The cycle has the advantage of being essentially an isothermal process; the phase change of the ammonia maintains the heat rejection surface in the dry tower at essentially the same temperature as the ammonia side of the condenser-reboiler.

Ammonia temperature wil1 vary with turbine backpressure, the range being about $27^{\circ} \mathrm{C}\left(80^{\circ} \mathrm{F}\right)$ to $66^{\circ} \mathrm{C}\left(150^{\circ} \mathrm{F}\right)$ and the normal operating temperature being about $46^{\circ} \mathrm{C}\left(115^{\circ} \mathrm{F}\right)$. Figure 3 shows the relationship between turbine backpressure and saturated steam temperature. ${ }^{(2)}$ since the transfer of heat from the condenser to the air involves phase change of the ammonia along the saturation line, pressure in the ammonia loop will also vary with turbine backpressure. Figure 4 shows the relationship between the boiling point of ammonia and the pressure. Pressure in the ammonia loop will range between $0.95 \mathrm{MPa}$ (138 psig) and $2.88 \mathrm{MPa}$ (418 psig), the normal operating pressure being about $1.73 \mathrm{MPa}$ (251 psig).

\section{CORROSION BEHAVIOR OF CANDIDATE MATERIALS}

Uhlig ${ }^{(4)}$ classifles the materials in Table 1 as Class $A$ for service in compressed liquid and gaseous anhydrous ammonia. Materials in Class A are suitable for critical parts where very little dimensional change can be tolerated and whose behavior is not likely to be altered materially by turbulence, changes in oxidizing or reducing power, or other incidental conditions of exposure. Monel 400, Monel K-500, $\mathrm{Cu}-\mathrm{Ni}$ alloys and copper 


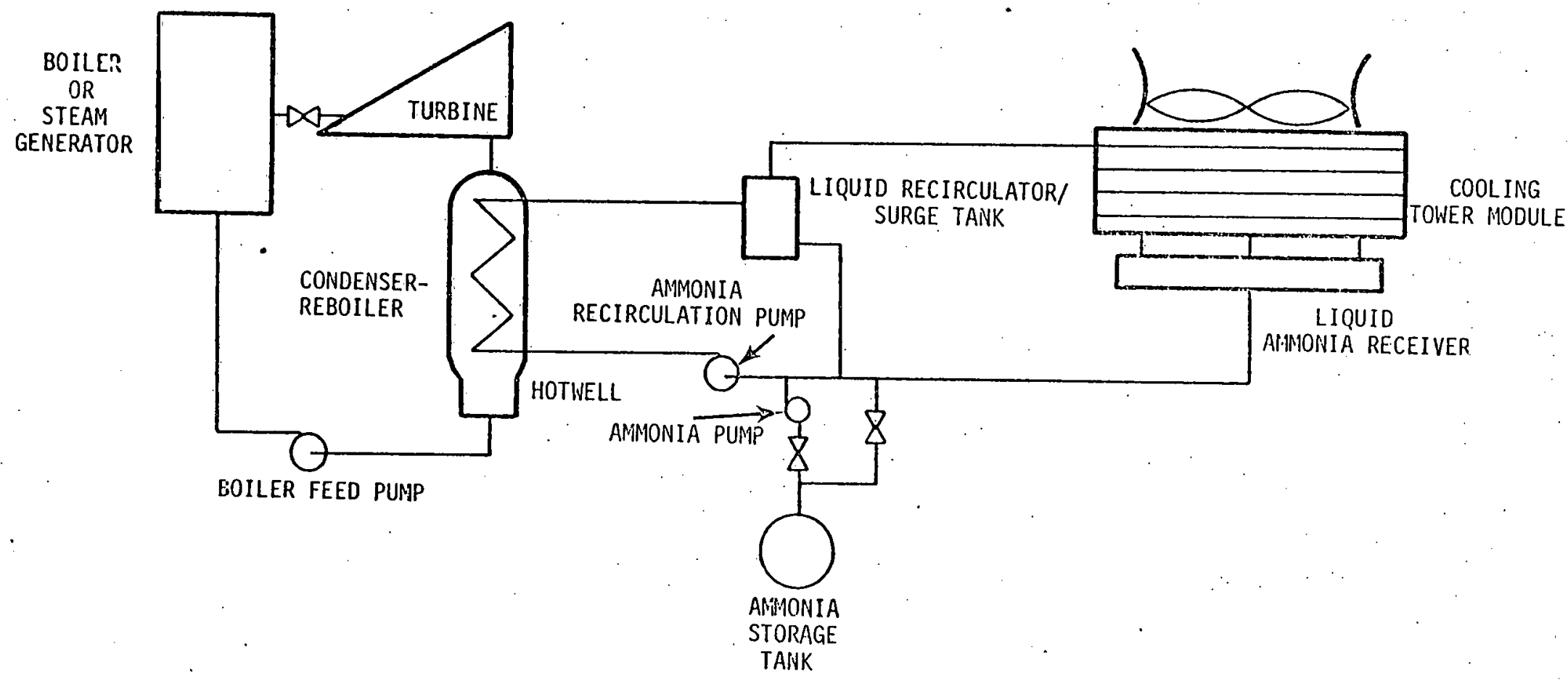

Figure 2. Simplified Schematic of Power Plant Ammonia Heat Rejection System. 
base alloys are listed as Class $\mathrm{C}$ materials; that is, materials not ordinarily considered suitable. These latter materials are eliminated as candidates because of their tendency to form amino copper complexes.

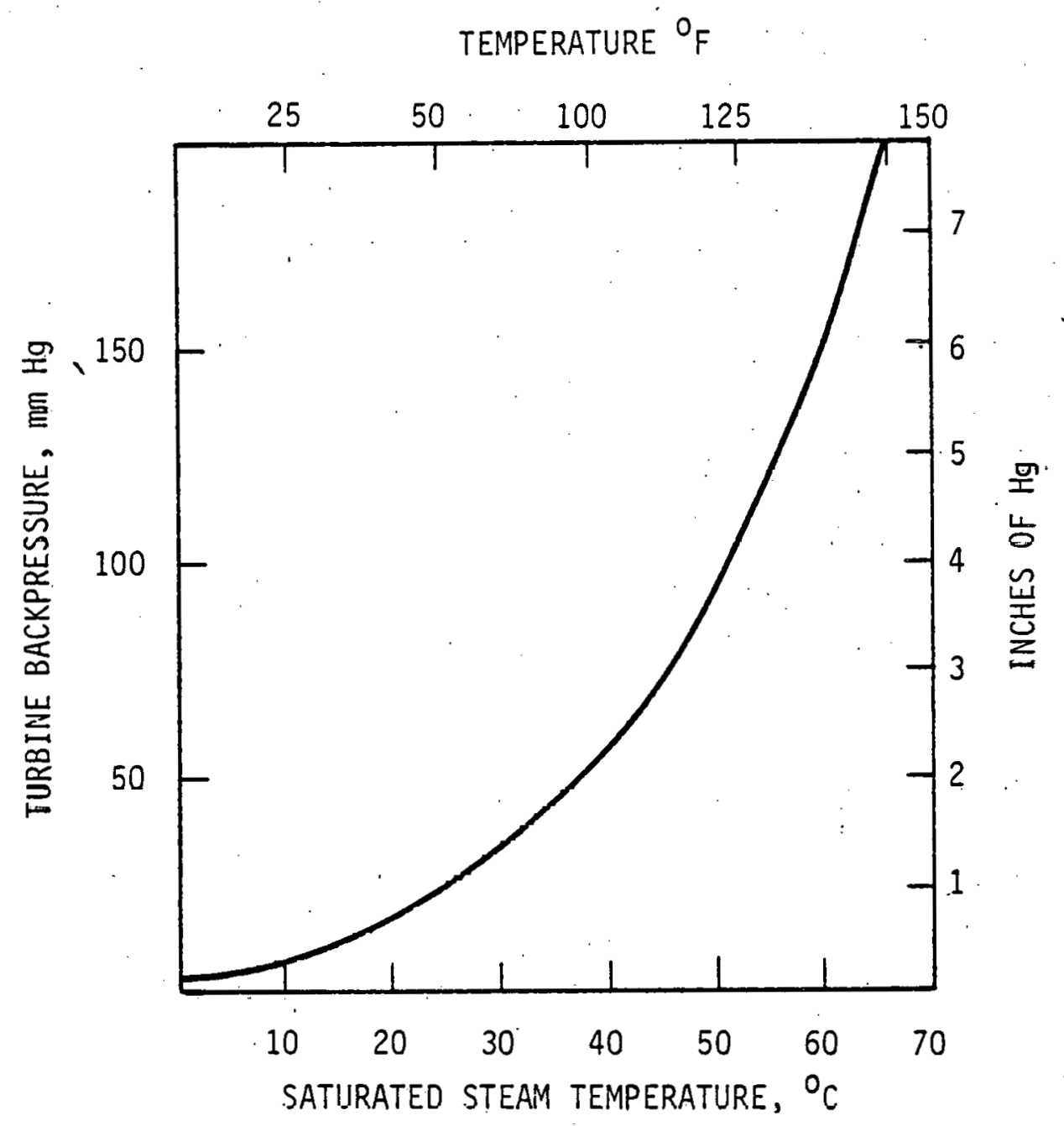

Figure 3. Relationship of · Turbine Backpressure to Saturated Steam Temperature. (2) 
The field of candidates can be further narrowed by cost considerations. Table $2^{(5)}$ shows recent cost data for pertinent materials.

Nickel alloys and magnesium alloys can be eliminated as candidate materials on the basis of cost. Lead is eliminated due to strength considerations. Thus the materials which can be considered as candidates for use in the ammonia cycle are aluminum alloys, carbon steel and stainless steel, with carbon steel being by far the least expensive.

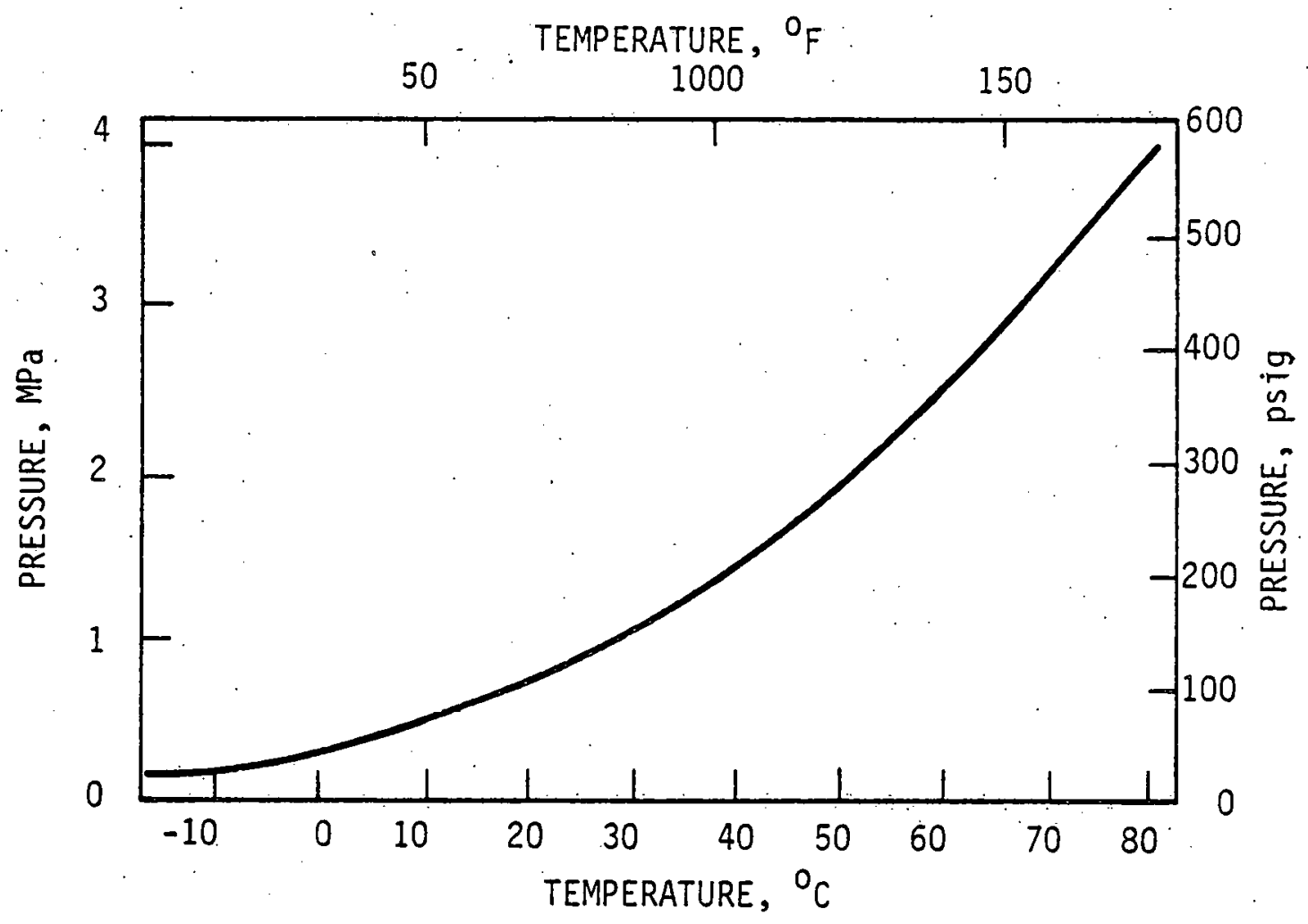

Figure 4. Dependence of Boiling Point of Ammonia on Pressure. (3) 
Table 1. Materials Resistant to Corrosion in Liquid and Gaseous Anhydrous Ammonia.

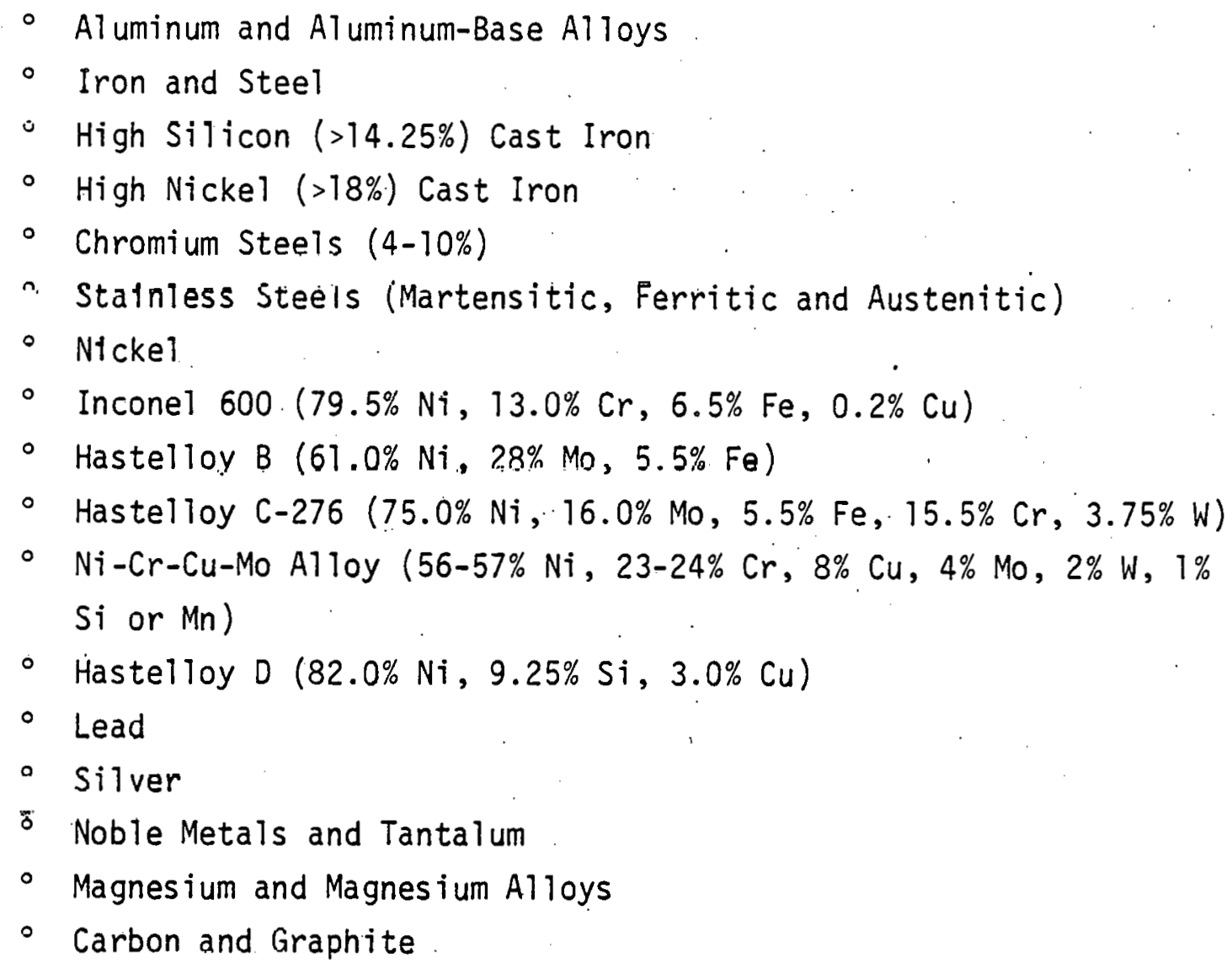




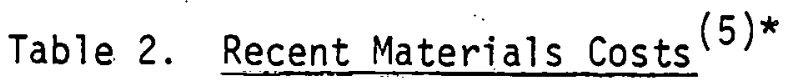

\begin{tabular}{ll}
\multicolumn{1}{c}{ Material } & Cost, $\$ / 1 \mathrm{~b}$ \\
Aluminum, Alloys 1100 and 3003 & $0.598-0.67$ \\
Aluminum, Alloy 6061 & 0.758 \\
Nickel, Alloy 200 & $3.53-3.71$ \\
Inconel 600 & $3.11-3.37$ \\
Lead & 0.19 \\
Carbon Steel, hot rolled & $0.11-0.12$ \\
Stainless Steel 304, 316, 321 & $0.52-0.93$ \\
Magnesium Alloys, wrought & 2.81
\end{tabular}

* These costs do not include the cost of fabrication. All prices as of about June 1975, generally for large quantities. Materials generally in sheet form.

In the following sections the corrosion performance of each of these groups of materials in ammonia is evaluated. The data presented are from the literature, laboratories currently conducting research in ammonia corrosion, and the field experience of ammonia producers and ammonia plant designers.

4.1 Aluminum and Aluminum Alloys

4.1.1 Corrosion of Aluminum In Anhydrous Ammonia and Concentrated Ammonia Solutions

Uhlig ${ }^{(4)}$ states that aluminum-base alloys are highly resistant to ammonia and ammonium hydroxide. Hillard and Mears ${ }^{(6)}$ cite an example of aluminum tubing used for handiing ammonia in a water cooler for over sixteen years. No serious attack occurred anywhere on this tubing, even adjacent to welds. Cross sections were cut through five regions of the tube, and the deepest penetration found was less than $0.25 \mathrm{~mm}(0.010 \mathrm{in}$.). 
Aluminum alloys $1100,3003,5052$ and 6063 showed only mild etching after one year of exposure in liquid ammonia containing $5 \% \mathrm{H}_{2} \mathrm{O}$ at $47^{\circ} \mathrm{C}$ $\left(117^{\circ} \mathrm{F}\right)$. These workers ${ }^{(6)}$ emphasize that ammonia has very little corrosive action on most aluminum alloys and point out that ammonia has been used in contact with al uminum at temperatures as high as $260^{\circ} \mathrm{C}$ $\left(500^{\circ} \mathrm{F}\right)$. Tseitlin, et at. ${ }^{(7)}$, state that aluminum and its copper-free alloys are compatible with gaseous ammonia at temperatures up to $450^{\circ} \mathrm{C}$ $\left(842^{\circ} \mathrm{F}\right)$.

Figure 5 shows the corrosion of aluminum alloy 1100 in $80 \%$, $90 \%$ and $100 \%$ ammonia. ${ }^{(8)}$ If the hlank. correction of $0.01 \mathrm{mg} / \mathrm{cm}^{2}$, which was not applied to these data, is considered, it is evident that very little corrosion occurred at ammonia concentrations of $90 \%$ to $100 \%$.

Figure 5 also indicates that corrosion of aluminum in highconcentration ammonia solutions virtually ceases after about ten days. Figure $\sigma^{(8)}$ shows that the initial corrosion rates and the total metal loss which occur as a result of this initial corrosion are negligible in anhydrous ammonia. The ratio of sample area to solution volume (A/V) appears to have no effect at ammonia concentrations greater than $30 \%$. As will be shown later, the $A / V$ ratio is a critical variable in dilute ammonia solutions.

Recent work at the U.S. Steel Research Laboratory confirms the conclusion of Bonewitz that corrosion of aluminum in anhydrous ammonia is negligible. In this study, aluminum alloy 3003 showed a weight gain of on $7 y 7.52 \mathrm{mg} / \mathrm{dm}^{2}$ after one month of exposure to liquid ammonia at room temperature. $(9)$

Of concern to the use of ammonia in a dry cooling application is the production of hydrogen during the initial contact period, before the aluminum surfaces become passivated. Hydrogen is produced according to the following reaction:

$$
\mathrm{Al}+\mathrm{OH}^{-}+\mathrm{H}_{2} \mathrm{O} \rightarrow \mathrm{AlO}_{2}^{-}+3 / 2 \mathrm{H}_{2} \text {. }
$$

This reaction is assumed because the lack of attack of aluminum in anhydrous ammonia indicates that the presence of water is necessary. 


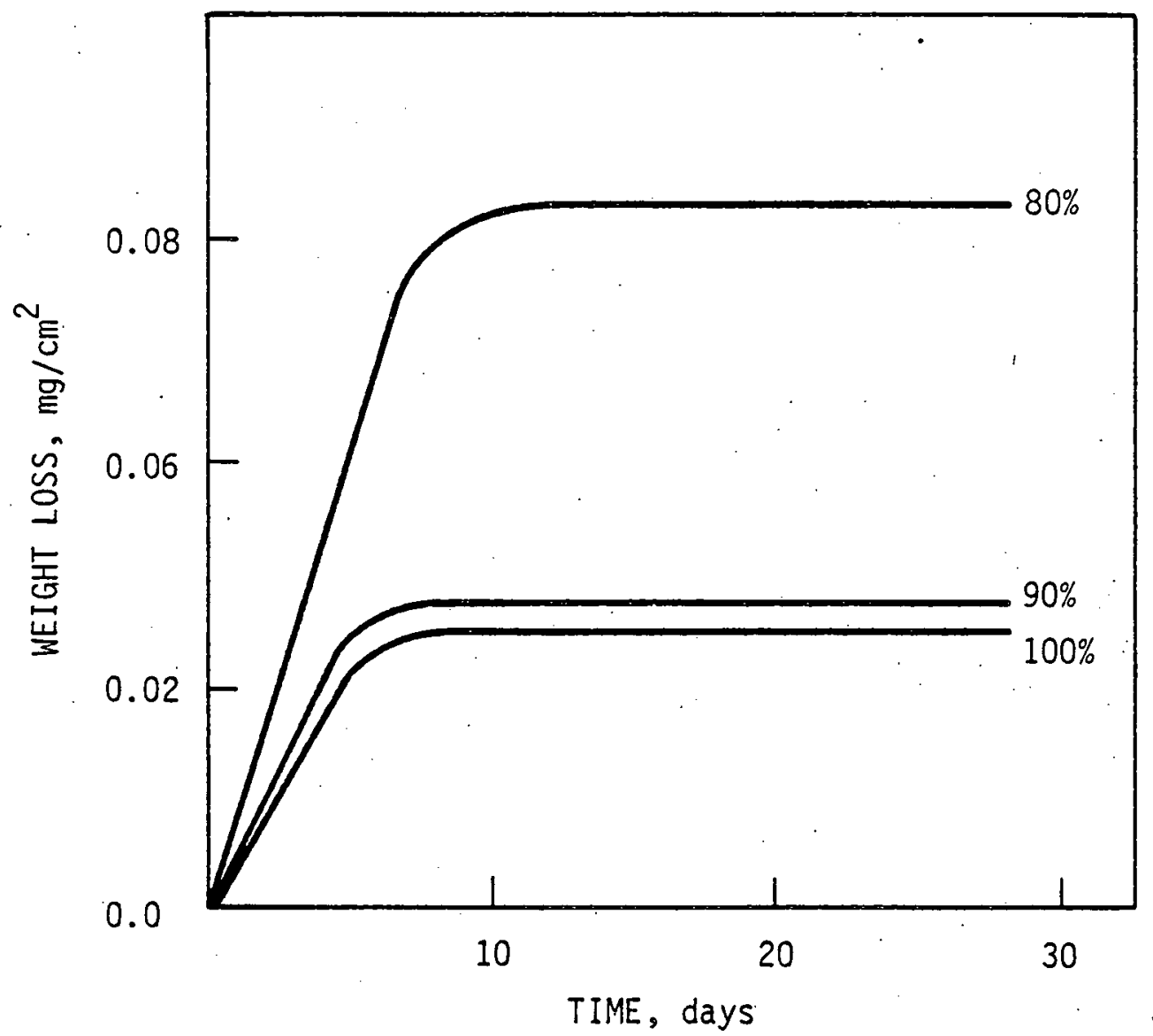

Figure 5. Corrosion of Aluminum Alloy 1100 in $80 \%, 90 \%$, and $100 \%$ Ammonia. (8) 


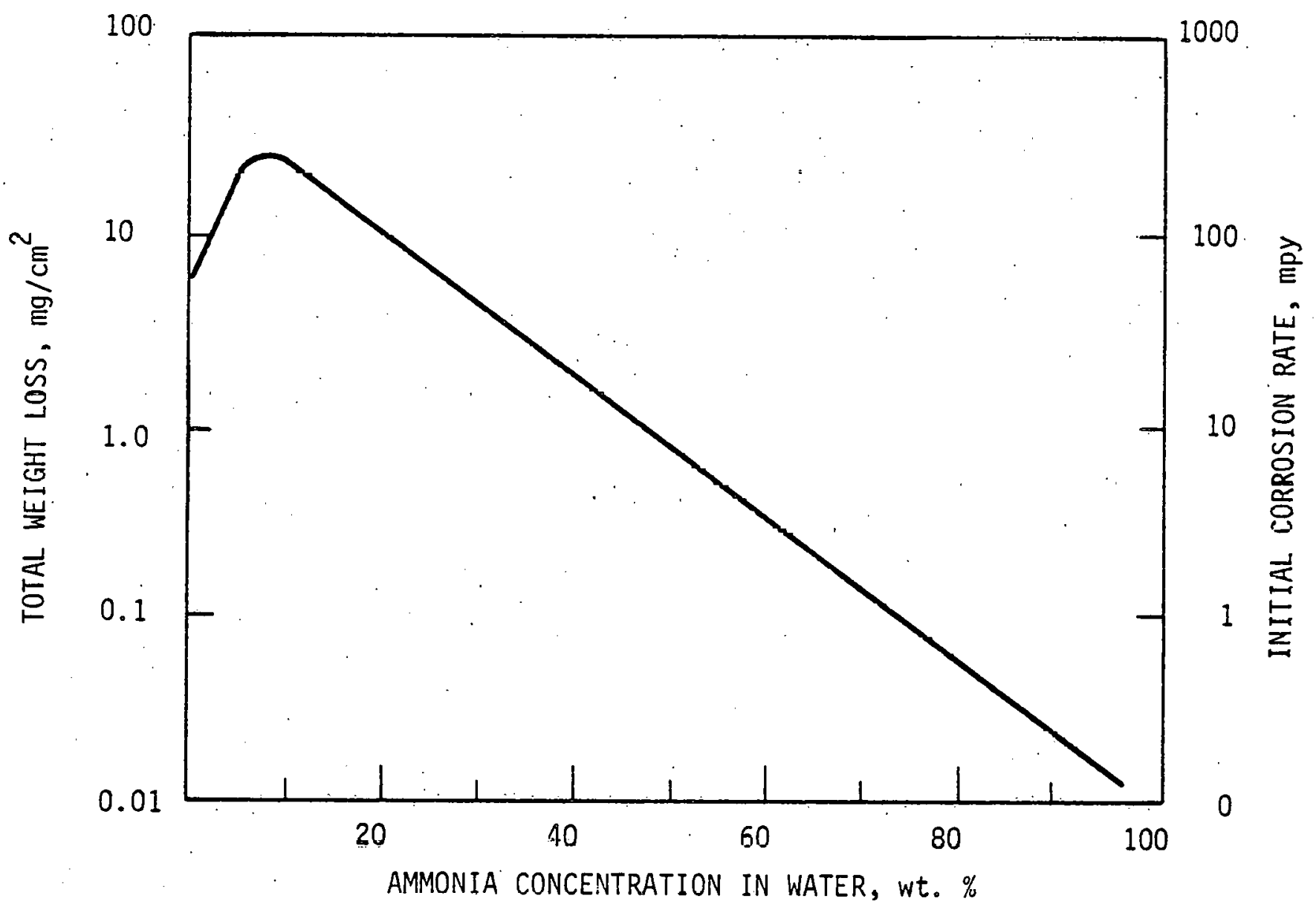

Figure 6. Total Weight Loss and Initial Corrosion Rates of Aluminum Alloy 1100 as a Function of Ammonia Concentration in water. (8) 
The presence of hydrogen in the ammonia cycle of a dry-cooled plant will decrease the cooling efficiency, and only a small rate of hydrogen generation can be tolerated. Water may be intentionally added to the ammonia at levels up to about $0.5 \%$ to inhibit stress-corrosion cracking of carbon steel components (this concept will be discussed later). Experience in gas absorption air conditioners which employ ammonia as a refrigerant indicates that a small amount of residual ammonia containing up to $40 \%$ water may remain in the evaporator.

In the condenser-reboiler of an ammonia-cooled plant, most of the aluminum surface will be exposed to anhydrous (or nearly so) liquid or gaseous ammonia. A small area, however, may be exposed to a small amount of unevaporated solution which can have a water concentration as high as $40 \%$. This area will corrode during an initial period of approximately ten days at a rate of about $4 \mathrm{mg} / \mathrm{dm}^{2} /$ day, creating approximately $0.1 \mathrm{ml} / \mathrm{cm}^{2} /$ day of evolved hydrogen. Pretreatment of aluminum surfaces in the condenser-reboiler to bring about passivation, thus reducing hydrogen generation during the initial service period, may be advisable. Manufacturers of gas absorption air conditioners handle the problem of hydrogen evolution by placing a hydrogen collection tank at a high point in the system. This tank is bled periodically to remove the hydrogen.

While the problem of hydrogen evolution due to corrosion may be somewhat more prominant with aluminum, some corrosion occurs with all materials, resulting in hydrogen evolution. Thus hydrogen collection tanks are required regardless of the material of construction.

\subsubsection{Corrosion of Aluminum in Dilute Ammonia Solutions}

The main mechanism for the formation of dilute ammonia solutions $(<30 \%)$ in a ammonia heat rejection system is leakage of ammonia through the condenscr-reboiler into the steam condensate. Among the causes of aluminum condenser-reboiler leaks is erosion on the steam/condensate side of the tubes caused by impingement of saturated, high velocity steam from the turbine. This problem has been discussed elsewhere; ${ }^{(10)}$ 
it can be reduced by the use of clip-on stainless steel sleeves on the first several rows of tubes or by the selective placement of stainless steel tubes in this area of the condenser-reboiler.

The effect of ammonia leakages through the condenser-reboiler on condensate and feedwater chemistry will be examined in a subsequent section. The effects of such leakages on the corrosion of the aluminum tubes will be examined in detail here.

Bonewitz $(8)$ reports that in dilute ammonia solutions (up to approximately $10 \%$ ), the initial rate of attack on aluminum is conntrniled by liquid phase diffusion of $\mathrm{OH}^{-}$ions to the aluminum surface and is, therefore, a function of solution $\mathrm{pH}$. Figure 7 shows the initial corrosion rates of aluminum alloys 1100 and 3003 as a function of pH and ammonia concentration. Above the concentration of about $10 \%$ ammonia in water this relationship between $\mathrm{pH}$ and initial corrosion rate is no longer observed. Above 10\% ammonia decreased initial rates of corrosion are observed. (8) (See Figure 6).

It has also been shown that weight loss of aluminum per unit of surface area is a function of the ratio of sample area to solution volume for dilute ammonia solutions. (8) Figure 8 illustrates this effect for aluminum alloy 1100 in $0.85 \%$ ammonia solution. This figure shows that after an initial period of about 40 to 60 hours, corrosion apparently ceases, indicating that passivation of the aluminum occurs, probably as a result of the solution near the metal surface becoming saturated with dissolved corrosion product. Table 3 shows the weight losses and bulk solution corrosion product concentrations for each sample size of aluminum alloys 1100 and 3003. (8) This table shows that, except for the smallest samples, corrosion ceased when the corrosion product in the bulk $0.85 \%$ solution reached an average concentration of $538 \mathrm{mg} \mathrm{Al/l}$ for alloy 1100 and $983 \mathrm{mg} \mathrm{Al/l}$ for alloy 3003 . Correspondingly, corrosion of alloy 1100 in $8.5 \%$ ammonia solution ceased when the bulk solution corrosion product concentration reached about $860 \mathrm{mg} \mathrm{AT/1}$; the $2.2 \mathrm{~cm}^{2}$ specimens, which weighed about $900 \mathrm{mg}$, were completely destroyed. 


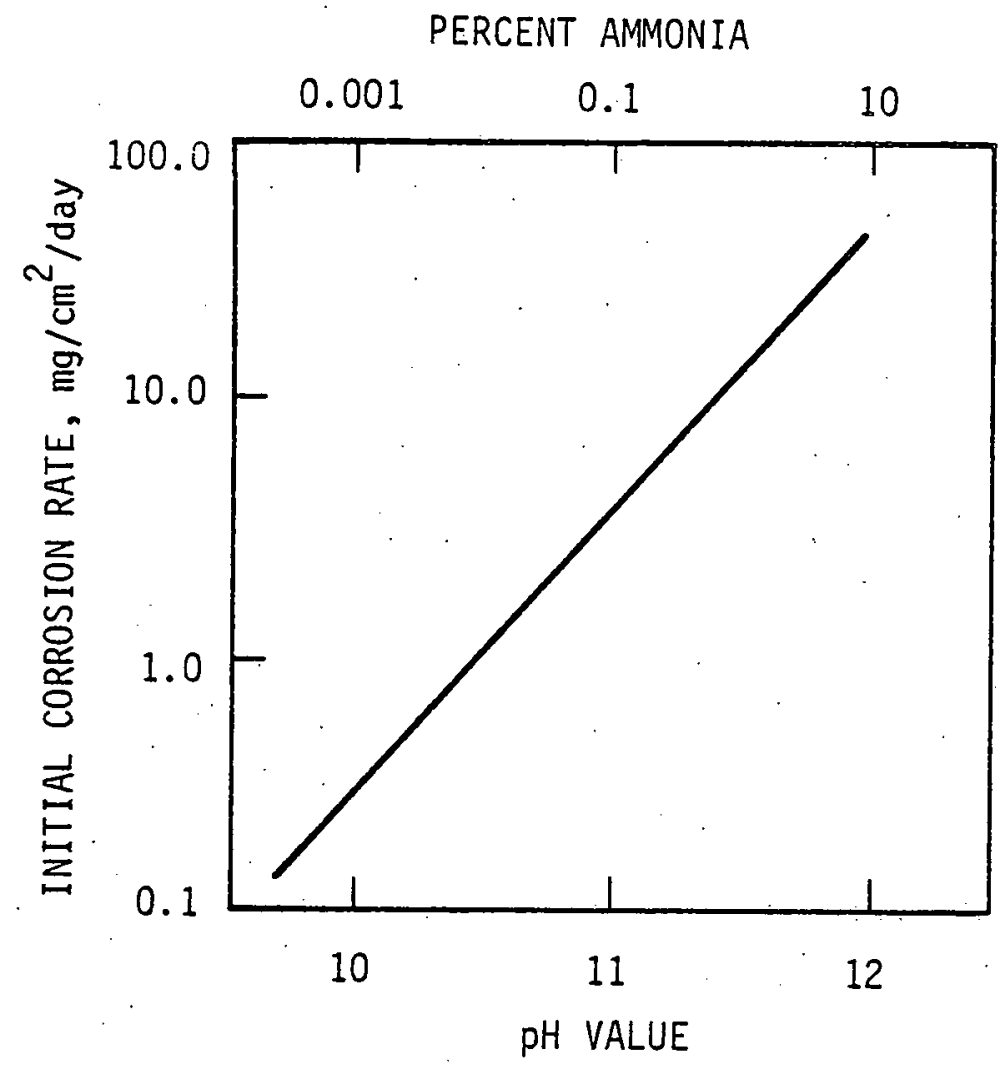

Figure 7. Initial Corrosion Rates of Aluminum Alloys 1100 and 3003 . as a Function of $\mathrm{pH}$ Controlled by Ammonia. (8)

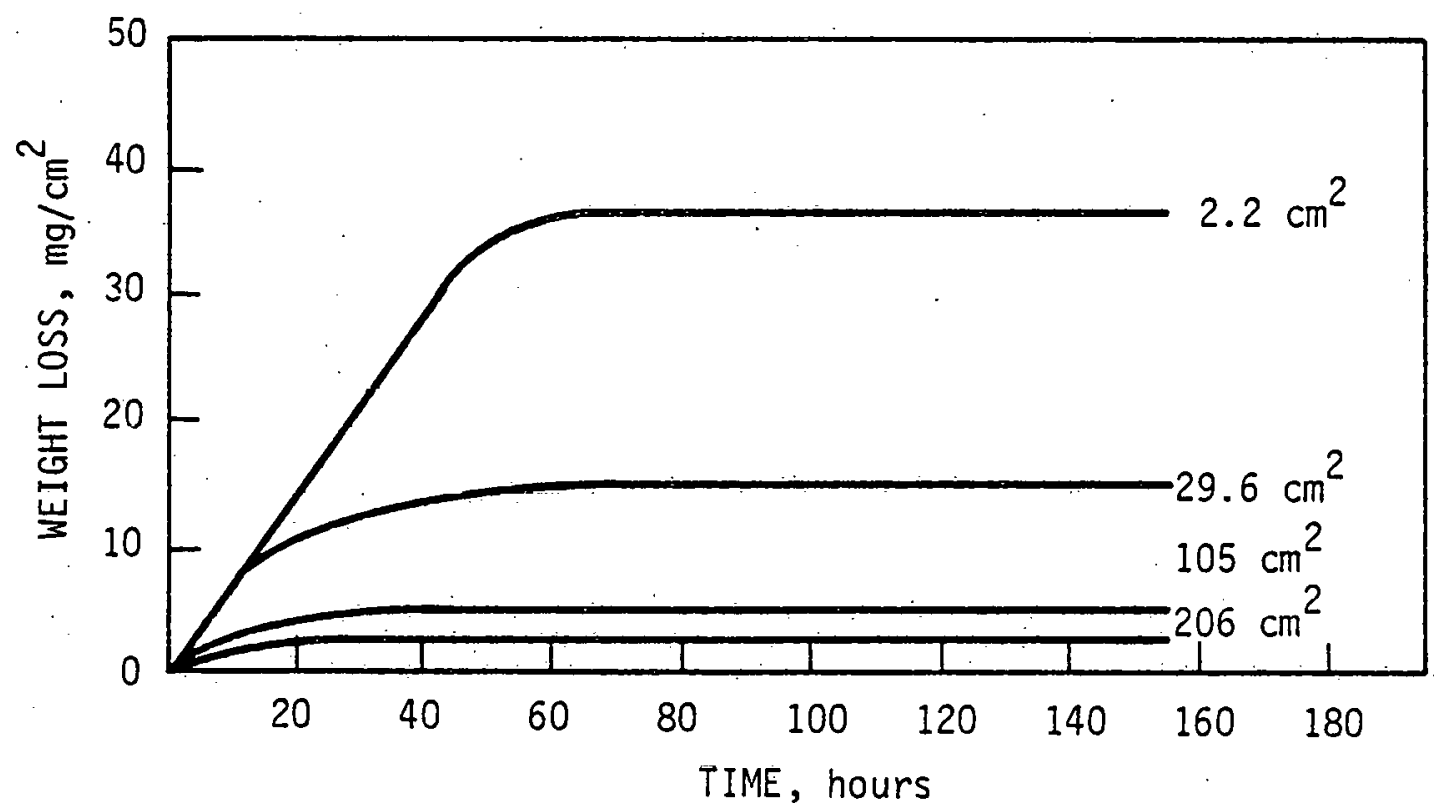

Figure 8. Corrosion of Aluminum Alloy 1100 Samples of Various Areas in Unrefreshed $0.85 \%$ Ammonia Solution. (8) 
Table 3. Corrosion of Aluminum Alloys 1100 and 3003 in Unrefreshed $0.85 \%$ Ammonia Solution.

2 Weight Loss, $\mathrm{mg} / \mathrm{cm}^{2} \quad \begin{aligned} & \text { Corrosion Product } \\ & \text { Concentration; } \mathrm{mg} / 1\end{aligned}$ Sample Size, $\mathrm{cm}^{2}$ Alloy 1100 Alloy 3003 Alloy 1100 Alloy 3003

$\begin{array}{rrrrr}2.2 & 36 & 49 & 99 & 135 \\ 29.6 & 12 & 27 & 444 & 999 \\ 105 & 5 & 7.5 & 656 & 984 \\ 206 & 2 & 3.8 & 515 & 965\end{array}$

These results indicate that once a critical concentration of corrosion product at the aluminum surface is reached (the magnitude of which depends on the rate of $\mathrm{OH}^{-}$ion diffusion to the surface and thus to the ammonia concentration), no further corrosion product can go into solution and corrosion ceases. However, under conditions of solution renewal, no buildup of corrosion product occurs, and corrosion is continuous. (8) Other workers have found that in $10 \%$ ammonia solution corrosion is continuous in renewed solution. (11)

In a dry cooling application, areas adjacent to small leaks in the aluminum condenser-reboiler will be subject to continuously refreshed solution; that is, corrosion products will be continuously swept away. This would result in continuing corrosion of the aluminum in the dilute solution formed by mixing of the ammonia and steam condensate. Thus a pin-hole leak in the condenser-reboiler caused by steam erosion could result in continuing corrosion of the aluminum tubes (a1loys 1100 and 3003 ) at a rate of between 10 and $100 \mathrm{mg} / \mathrm{cm}^{2} /$ day (see Figure 7 ). Serious ammonia leakages and condenser-reboiler tube failures would result in $a$ short time.

The situation may be more encouraging for aluminum alloys containing magnesium, such as alloys 5052 and 6061 . These alloys have been noted for their superior performance in alkaline solution due to 
lower solubility of their oxide fi.lms: Bonewitz ${ }^{(8)}$ indicates that these alloys may be expected to perform satisfactorily in dilute ammonia solution, but further studies are required.

\subsubsection{Galvanic Attack of Aluminum}

In studies conducted by $A T$ coa $(12)$ to evaluate the compatability of ammonia with aluminum cargo tanks, it was found that aluminum coupled with carbon steel suffers accelerated corrosion due to galvanic action between the two metals. Similar galvanic effects were observed with al uminum vs. $\mathrm{Fe}_{3} \mathrm{O}_{4}$. The presence of air is necessary for this corrosion to proceed, and the addition of water to a concentration of 0.2 to $0.5 \%$ effectively inhibits the corrosion. As will be discussed later, water should be added at about this concentration to ammonia in contact with carbon steel to inhibit stress-corrosion cracking.

Jones and Wilde ${ }^{(9)}$ have developed a cadmium-saturated cadmium chloride reference electrode to measure the electrochemical potential of alloy surfaces in liquid ammonia at room temperature and elevated pressure. A galvanic series of various metals and alloys in liquid. ammonia has been established using this electrode; this series is shown in Figure 9 for both uncontaminated and air-contaminated liquid ammonia. Tests conducted by these workers have shown that aluminum, when coupled to steel, acts as a sacrificial anode and cathodically protects the stee 1 against stress-corrosion cracking in air-contaminated ammonia. (9)

\subsubsection{Use of Aluminum in OCT Ammonia Cycles}

Overall it appears that aluminum is a good choice of material for use in the condenser-reboiler of a power plant using the ammonia dry cooling cycle provided the tubes are protected from steam impingement. This conclusion is based on the susceptibility of aluminum to erosion by high-velocity saturated steam and accelerated corrosion of the aluminum tubes which would result from leakage of ammonia into the steam condensate. Aluminum is a suitable material for use in the dry cooling 


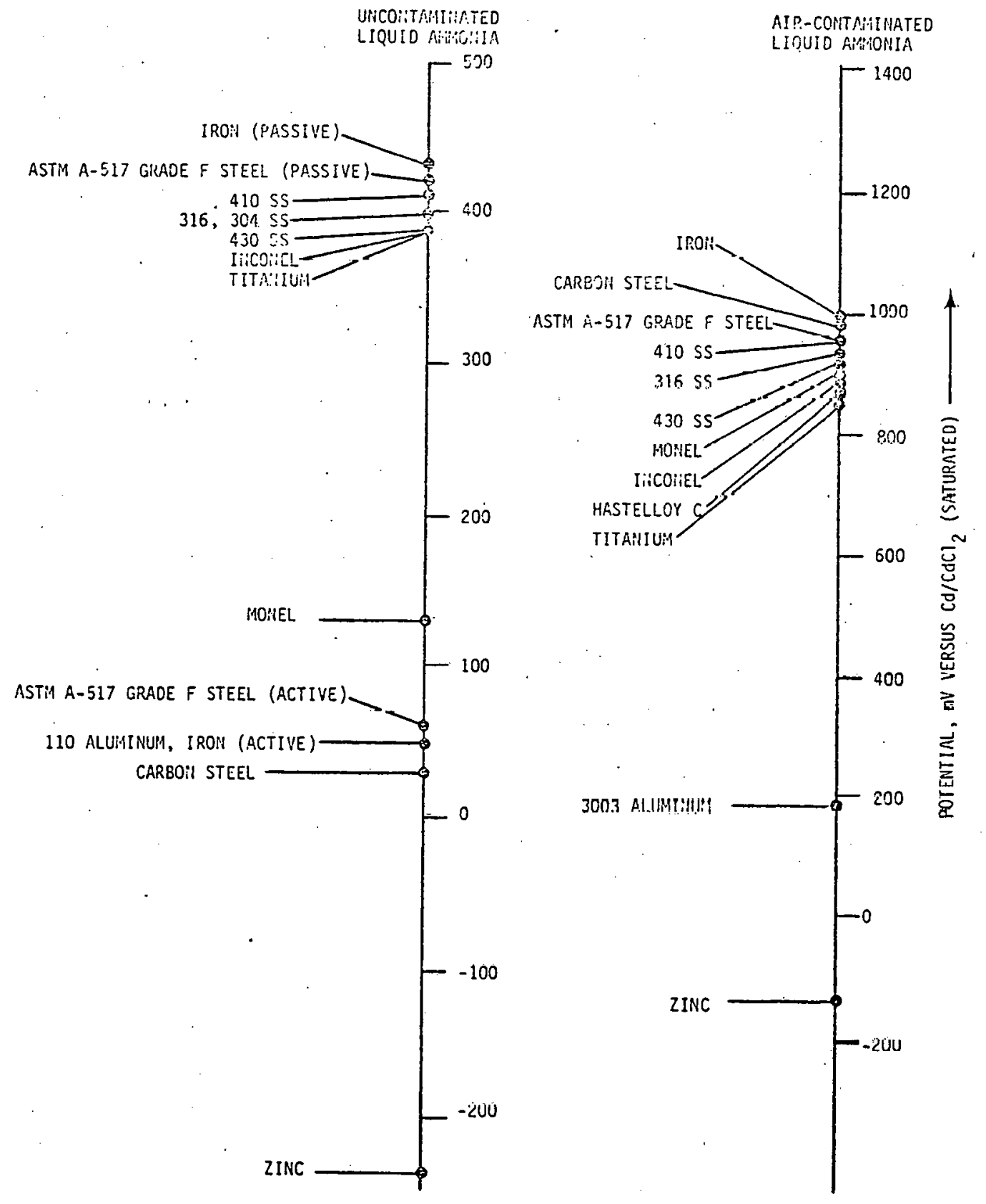

Figure 9. Gatovanic "Series of Various Metals and Alloys in Liquid Ammonia. (9) 
tower where steam erosion and corrosion in dilute ammonia solutions are not a problem. Further studies may show that the aluminum alloys containing magnesium are most suitable for use in the condenser-reboiler. If aluminum is coupled with steel, water. $(20.5 \%)$ should be added to the ammonia to inhibit galvanic attack of the aluminum.

\subsection{IRON-BASE ALLOYS}

\subsubsection{General Corrosion Behavior of Iron-Base Alloys in Liquid Ammonia}

Jones and Wilde ${ }^{(9)}$ have shown that iron-base alloys do not experience appreciable general corrosion when exposed to liquid anhydrous ammonia over a period of several months. The general corrosion performance of various materials, including iron-base alloys, in liquid ammonia is shown in Table 4.

\subsubsection{General Service Experience and Corrosion Behavior of Carbon Steel}

Anhydrous ammonia has been used in commercial service for the past 60 years. Carbon steel has been the major material used for the handling and storage of anhydrous ammonia. No appreciable difficulties with steel equipment used for handling and storing ammonia have been experienced in the chemical and refrigeration industries. (13) Carbon steel is used satisfactorily by the ammonia production industry in ammonia coolers, condensers, separators and associated piping. ${ }^{(14,15)} \mathrm{A}$ summary of the design parameters of some of this equipment pertinent to dry-cooling applications is given in Appendix 7.1. Maximum allowable velocities in ammonia handling equipment are $5.1 \mathrm{~m} / \mathrm{sec}(16.7 \mathrm{ft} / \mathrm{sec})$ for 1 iquid ammonia and about $33.5 \mathrm{~m} / \mathrm{sec}(110 \mathrm{ft} / \mathrm{sec})$ for gaseous ammonia.

In the early 1950's the practice of direct application of anhydrous ammonia to the soil as a fertilizer began. At that time a large number of steel pressure vessels were placed in service for agricultural ammonia storage, transport and application. A number of 
Table 4. General Corrosion Performance of Various Materials in Liquid Ammonia $(9)$

Alioy

Designation

Type 304 SS

Type 316 .SS

Type 430 SS

Type 410 SS

Aluminum Alloy 3003

A1 uminum A1 loy 5454

Titanium

Monel

Inconel 600

Zinc

Iron

Carbon Steel

Hastalloy C

ASTM A-517. Grade F Steel

* + means weight gain

- means weight loss

\begin{tabular}{cc}
\multicolumn{2}{c}{ Weight Change, ${ }^{*} \mathrm{mg} / \mathrm{dm}^{2}$} \\
\cline { 1 - 2 } One-Month Exposure & Eight-Month Exposure \\
\cline { 1 - 2 } 0 & +3.0 \\
0 & +3.4 \\
0 & +3.8 \\
-7.52 & +0.75 \\
+7.52 & +1.9 \\
+12.8 & +1.12 \\
0 & +3.0 \\
-1.5 & -3.4 \\
-1.5 & +2.6 \\
-47.0 & -21.0 \\
-2.25 & -1.5 \\
-3.76 & -0.75 \\
-1.13 & +0.75 \\
-3.0 & -0.75
\end{tabular}


failures of these tanks occurred; a survey indicated that three percent of the tanks in agricultural service had failed during an average of three years service because of minor leaks from what proved to be stress-corrosion cracking.

Between the mid-1950's and about 1967, the service performance of ammonia transport trucks constructed of high-strength quenched and tempered steels was excellent. (17) In 1967, however, problems with stress-corrosion cracking began to occur in ammonia-carrying trucks made from this type of steel. This may have been due to a gradual increase in the purity of the ammonia being transported; the concentrations of impurities (water, as it will be shown later) which inhibit stresscorrosion cracking was reduced. The problem was still encountered in 1971, even after the U.S. Department of Transportation adopted more stringent rules regarding ammonia purity in an attempt to eliminate those impurities contributing to the problem.

Other incidents of failures of ammonia handling equipment have had more serious consequences. In 1968 an ammonia tank truck constructed of high-strength quenched and tempered steel ruptured in Lievin, France, killing five people. (18) Cause of this incident was attributed to corrosion cracking aggravated by fatigue. In 1973 a pressurized-storage ammonia tank in Potchefstroom, South Africa failed, releasing a total of 38 tons of anhydrous ammonia and killing 18 people. (19) Extensive metallurgical examination of the ruptured tank indicated that the failure was a result of brittle fracture; the vessel was not stress relieved after manufacture, and the metal had been weakened by strain aging. No evidence of stress-corrosion cracking was found. (19)

Recognizing the stress-corrosion problems which became evident soon after anhydrous ammonia came into wide-spread use as a fertilizer, the Agricultural Ammonia Institute (AAI) formed a Research Committee in 1954 to investigate the causes of failure of pressure vessels in anhydrous ammonia service. (16) An extensive research program was begun to confirm that stress-corrosion cracking was indeed the problem and to establish 
the agents in ammonia responsible for the cracking. (13) The results of research by this committee and by other workers will be summarized in the following paragraphs..

\subsubsection{Stress-Corrosion Cracking of Carbon Steels}

The first aim of the work conducted by the AAI Research

Committee was to devise and test steel specimens to establish whether stress-corrosion cracking was actually occurring. Tuning fork test specimens were devised and tested in stressed only, cold-worked and stressed, and cold-worked, welded and stressed conditions. Steels tested in this initial phase of the program are shown in Table 5 (13) Specimens were exposed under field conditions in 3785 liter (1000 galion) nurse tanks and 380 to 945 liter (100 to 250 gallon) applicator tanks containing agricultural grade anhydrous ammonia. The specimens were inspected for fracture or obvious cracking about once every three months.

\section{Table 5. Steels Tested in Initial Phase of AAI Research Committee Program ${ }^{(73)}$}

\section{Steel} ASTM A-212 Grade B ASME Case 1056 ASTM A-202 Grade B Compositton $0.33 \% \mathrm{c}, 0.77 \% \mathrm{Mn}, 0.24 \% \mathrm{Si}$ $0.30 \% \mathrm{C}, 1.13 \% \mathrm{Mn}$

\begin{tabular}{|c|c|}
\hline $\begin{array}{c}\text { Yield } \\
\text { Strength } \\
\text { ksi } \\
\end{array}$ & $\begin{array}{l}\text { Percent } \\
\text { Failure }\end{array}$ \\
\hline 51 & 0 \\
\hline 48 & 30 \\
\hline 57 & 27 \\
\hline
\end{tabular}

ASTM A-517 Grade F $0.19 \% \mathrm{C}, 1.46 \% \mathrm{Mn}, 0.77 \% \mathrm{Si}$ $0.45 \% \cdot C r$.
$0.16 \% \mathrm{C}, 0.88 \% \mathrm{Mn}, 0.22 \% \mathrm{Si}$, 116 74 $0.34 \% \mathrm{Cu}, 0.84 \% \mathrm{Ni}, 0.53 \% \mathrm{C}$, $0.48 \%$ Mo

The results of this test are shown in Table $6^{(13)}$ During a five-year exposure period, 82 of a total of 161 stressed tuning-fork specimens failed. As can be seen from the table, the most severely stressed specimens were those in the cold-worked, welded and stressed 


\section{Table 6 Effect of Specimen Condition and Stress Level on Stress-Corrosion Cracking of Tuning-Fork Specimens in Agricultural Ammonia (13)}

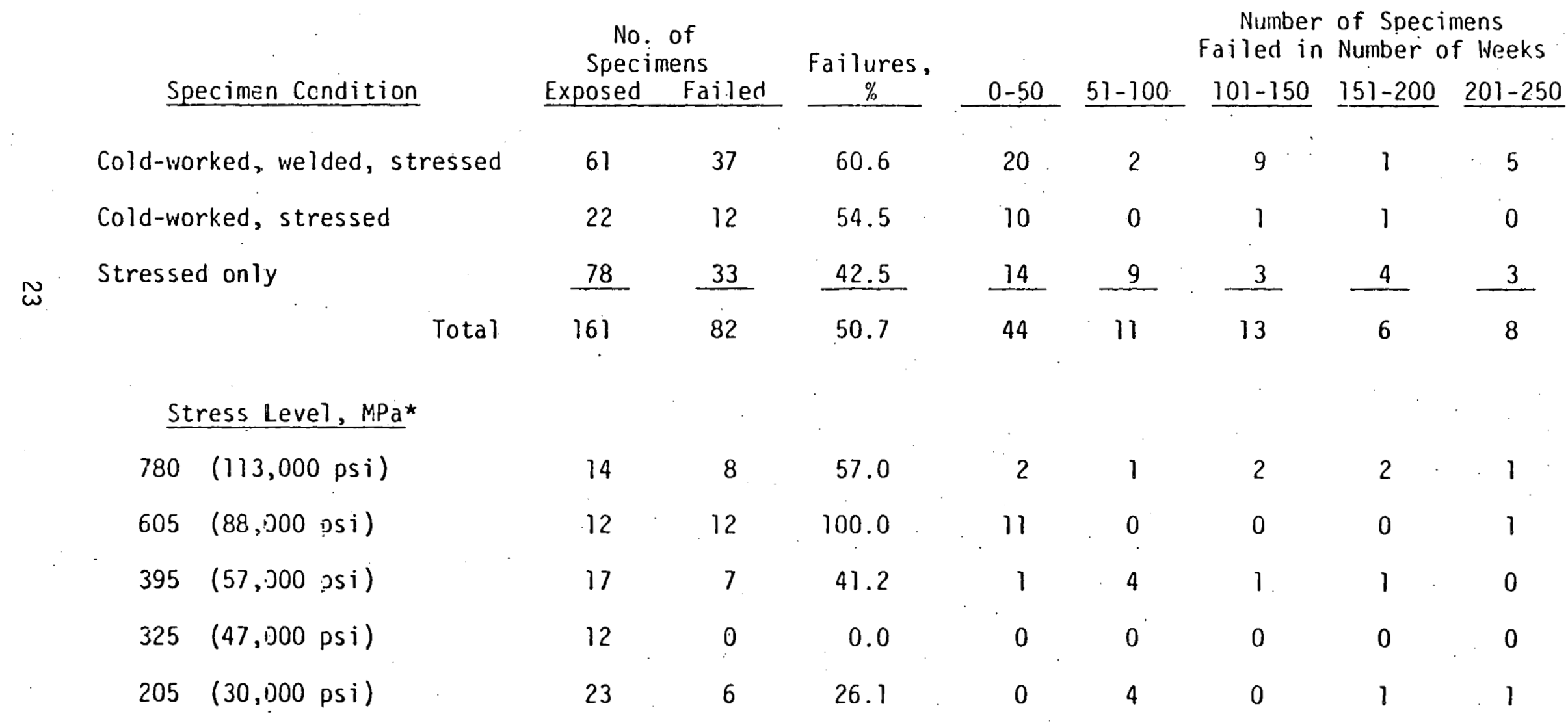

*Data obtained with stressed-cnly specimens 
condition, in which the specimens were at a very high stress level and a heat-affected zone was present. Next most severe was the cold-n'orked and stressed condition, followed by the stressed-only condition. (13)

An important trend shown in Table 6 is that, with some discrepancies, steels with higher yield strength cracked more readily than the lower-strength steels. Failures occurred more readily in the A-517 Grade $F$ steel, with a yield strength of $800 \mathrm{MPa}(116,000 \mathrm{psi})$, than in the other steels with substantially lower yield strengths. In this test $74 \%$ of the $A-517$ Grade $F$ steel specimens failed, $30 \%$ of the ASME Case 1056 steel specimens failed, and 27\% of the A-202 Grade B steel specimens failed. None of the $A-212$ Grade $B$ steel specimens failed, a fact that is not consistent with reported stress-corrosion failures of vessels made of this steel. (13)

\subsubsection{Causes and Inhibition}

Following the determination that stress-corrosion cracking was indeed the cause of the failures of pressure vessels used for handling and storing ammonia, the program sponsored by the AAI Research Committee was broadened to determine the specific ammonia contaminants which cause cracking and to identify an inhibitor that could be added to the ammonia in small amounts to prevent stress-corrosion cracking. In a second phase of the study, the effects of air, water and other possible contaminants were studied in refrigeration-grade ammonia.

Table 7 shows the results of an initial series of tests of A-517 Grade F and AISI 4130 steels (both of which have high yield strengths) in refrigeration-grade ammonia to which air and various amounts of water were added. (13) These results suggest that air in ammonia causes stress-corrosion cracking and that water is an effective inhibitor. However, the test ammonia was not analyzed and may have contained some air; this may explain why the failure frequency in uncontaminated ammonia was about the same as it was in the ammonia contaminated with air. Further tests showed that in ammonia the combined 
presence of air and carbon dioxide is necessary for the occurrence of stress-corrosion cracking.

These studies also showed that failures of steel specimens by stress-corrosion cracking in ammonia continue to occur after long exposure periods. Figure 10 shows a plot of the cumulative cracking frequencies of tuning-fork specimens with time. These specimens were exposed in ammonia without added water at various test locations. This figure shows that the highest rate of cracking occurs during the first year, but failures occurred even after five years.

Table 7. Effects of Air and Water Additions on Stress-Corrosion Cracking of High-Strength Steels in Refrigeration-Grade Ammonia $(13)$

\begin{tabular}{|c|c|c|c|c|}
\hline $\begin{array}{l}\text { Additions } \\
\text { Air } \\
\end{array}$ & $\begin{array}{l}\text { to Ammonia } \\
\text { Water \% }\end{array}$ & $\begin{array}{c}\text { No. } \\
\text { Exposed }\end{array}$ & $\begin{array}{l}\text { Specimens* } \\
\text { No. of } \\
\text { Failures }\end{array}$ & $\begin{array}{c}\text { Frequency, } \\
\frac{\%}{1}\end{array}$ \\
\hline No & 0.0 & 14 & 3 & 21.4 \\
\hline Yes & 0.0 & 44 & 10 & 22.8 \\
\hline Yes & 0.10 & 4 & 0 & 0 \\
\hline Yes & 0.25 & 4 & 0 & 0 \\
\hline Yes & 0.50 & 14 & 0 & 0 \\
\hline Yes & 1.0 & 14 & 0 & 0 \\
\hline Yes & 2.0 & 10 & 0 & 0 \\
\hline Yes. & 4.0 & 10 & 0 & 0 \\
\hline
\end{tabular}

*ASTM A-517 Grade F and AISI 4130 steel tuning-fork specimens in the cold-worked, welded and stressed condition. 


$$
\square
$$


This early work resulted in several recommendations from the AAI Research Committee, with the statement that all of these recommendations should be followed if stress-corrosion cracking of ammonia vessels was to be avoided. These recommendations were as follows: (17) (1) agricultural ammonia should contain $0.2 \%$ water as an inhibitor; extreme care should be exercised to avoid air contamination in ammonia systems; and (3) vessels over $36 \mathrm{in.}$ in diameter should be either fully stress-relieved or fabricated with heads that are hot-formed or stressrelieved.

In 1971, following inspections which revealed that stresscorrosion cracking of ammonia transport trucks was continuing despite the adoption of rules designed to prevent it, ${ }^{(20)}$ a.meeting was called by the U.S. Department of Transportation to review all aspects of stresscorrosion cracking in ammonia. (17) At this meeting the effectiveness of water as an inhibitor of stress-corrosion cracking was questioned, and it was suggested that the problem is really one of hydrogen embrittlement. As a result of these questions further studies were initiated to reevaluate the effectiveness of water as an inhibitor, investigate the hydrogen embrittlement question, and determine the actual concentration of air in ammonia which causes stress-corrosion cracking.

This more recent work has made use of a constant slow strain rate procedure to determine the influence of contamination and water additions on the stress-corrosion cracking behavior of A-517 Grade $F$ steel. In this test a tension specimen is slowly strained (strain rate $=2 \times 10^{-6} \mathrm{in} / \mathrm{in} / \mathrm{sec}$ ) while exposed to a liquid ammonia environment at $25^{\circ} \mathrm{C}\left(77^{\circ} \mathrm{F}\right)$. This test can quickly indicate the metal-environment combinations that result in stress-corrosion cracking.

In general, stress-corrosion cracking markedly reduces the ductility of the specimen and results in the formation of a number of secondary cracks in the gauge length. A non-aggressive environment, on the other hand, results in cup-cone fracture with normal ductility. Severe loss of ductility is therefore a positive indication of susceptibility 
to stress-corrosion cracking. However, tests conducted at Southwest Research Institute have shown that specimens exhibiting little or no loss in ductility frequently exhibit secondary cracking, indicating their susceptibility to stress-corrosion cracking. Therefore, a high ductility is not sufficient evidence to classify a specific ammonia as a non-cracking environment; visual examination of specimen surfaces for the presence of secondary cracking is also required.

In this test, percent reduction in area (\%RA) is used ds a cracking index. Values of \%RA markedly lower than control values are indicative of stress-corrosion cracking.

Because of the skepticism expressed regarding the effectiveness of water inhibition of stress-corrosion cracking in ammonia, a series of tests was conducted at U.S. Steel Corporation's research laboratory in which water additions were made to air-contaminated ammonia. The results are presented in Figure 11 for water additions over the range of 0.02 to 1.2 weight percent. (21) These data show that the previous findings $(13)$ were correct: the addition of $0.2 \%$ water inhibits stresscorrosion cracking of high-strength steels in air-contaminated liquid ammonia. Recent studies of line-pipe steels also confirm these results.

It has been learned through recent communication with the personnel at U.S. Steel ${ }^{(23)}$ that while no index of aggressiveness of ammonia vapor versus ammonia liquid has been established, stress-corrosion cracking of structural steels has occurred in both air-contaminated ammonia vapor and liquid ammonia. In work conducted at U.S. Steel, water added to the liquid phase has been found to be effective in inhibiting stress-corrosion cracking of structural steels in the vapor phase. However, experience is limited in this area and data is conflicting.

Work completed recently at Southwest Research Institute ${ }^{(24)}$ has suggested that there may be a critical zone of potential for stresscorrosion cracking of steel in contaminated ammonia. The effect of oxygen and water on the corrosion potential and its relation to the 


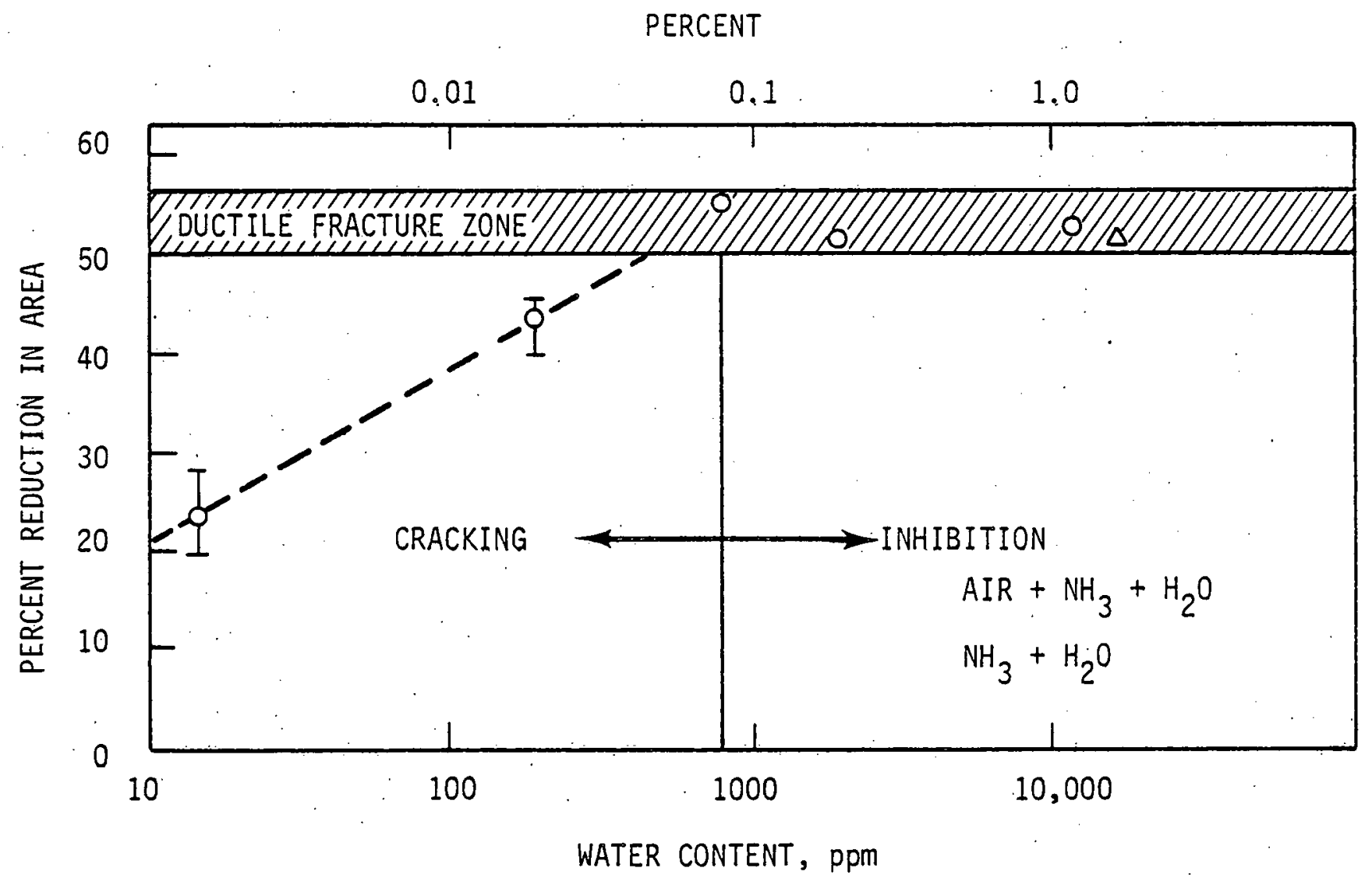

Figure 11. The Influence of Water Content on the Stress Corrosion Cracking Susceptibility of A517 Grade F Steel in Air Contaminated Liuqid Ammonia. (21) 
proposed critical zone is 11 lustrated in Figure 12. It is postualated that stress-corrosion cracking occurs between potentials $E_{x}$ and $E_{y}$ on the iron oxidation curve, and raising or lowering $E_{\mathrm{O}_{2}} / \mathrm{H}_{2} \mathrm{O}$ can cause or prevent stress-corrosion cracking by moving $E_{\text {corr }}$ into or out of the potential zone between $E_{x}$ and $E_{y}$. These workers have shown that in certain ammonias with moderate concentrations of contaminants, low concentrations of water are capable of causing cracking. For example, one sample did not cause cracking but when $300 \mathrm{ppm}$ water was added, severe cracking occurred. A statistical equation was developed from which it may be predicted whether a particular ammonia will cause cracking; use of the equation requires that the concentrations of $\mathrm{O}_{2}, \mathrm{~N}_{2}, \mathrm{CO}_{2}, \mathrm{CH}_{4}$, and $\mathrm{H}_{2} \mathrm{O}$ be known. (24)

A summary of test environments used and stress-corrosion cracking results obtained at U.S. Steel is given in Table 8 . Tests conducted in air-contaminated ammonia evidenced a marked decrease in \%RA along with clear evidence of secondary stress-corrosion crack formation adjacent to the main fracture face. Metallographic examination of specimens at areas close to the main fracture face revealed tight branching cracks typical of stress-corrosion cracking. (21)

Table 8. Stress-Corrosion Test Data on A-517 Grade F Steel (21)

Environment

Laboratory $\Lambda$ ir

(Control Test)

Uncontaminated

Ammonid

Air-Contaminated

Ammonia
Ave. \%RA

53

52

24
Observations Ductile cup-cone
fracture

Ductile cup-cone fracture

Low ductility, secondary cracks evident

The vapor phase above the various ammonia samples used in the above tests was analyzed using a gas chromatographic procedure. The 


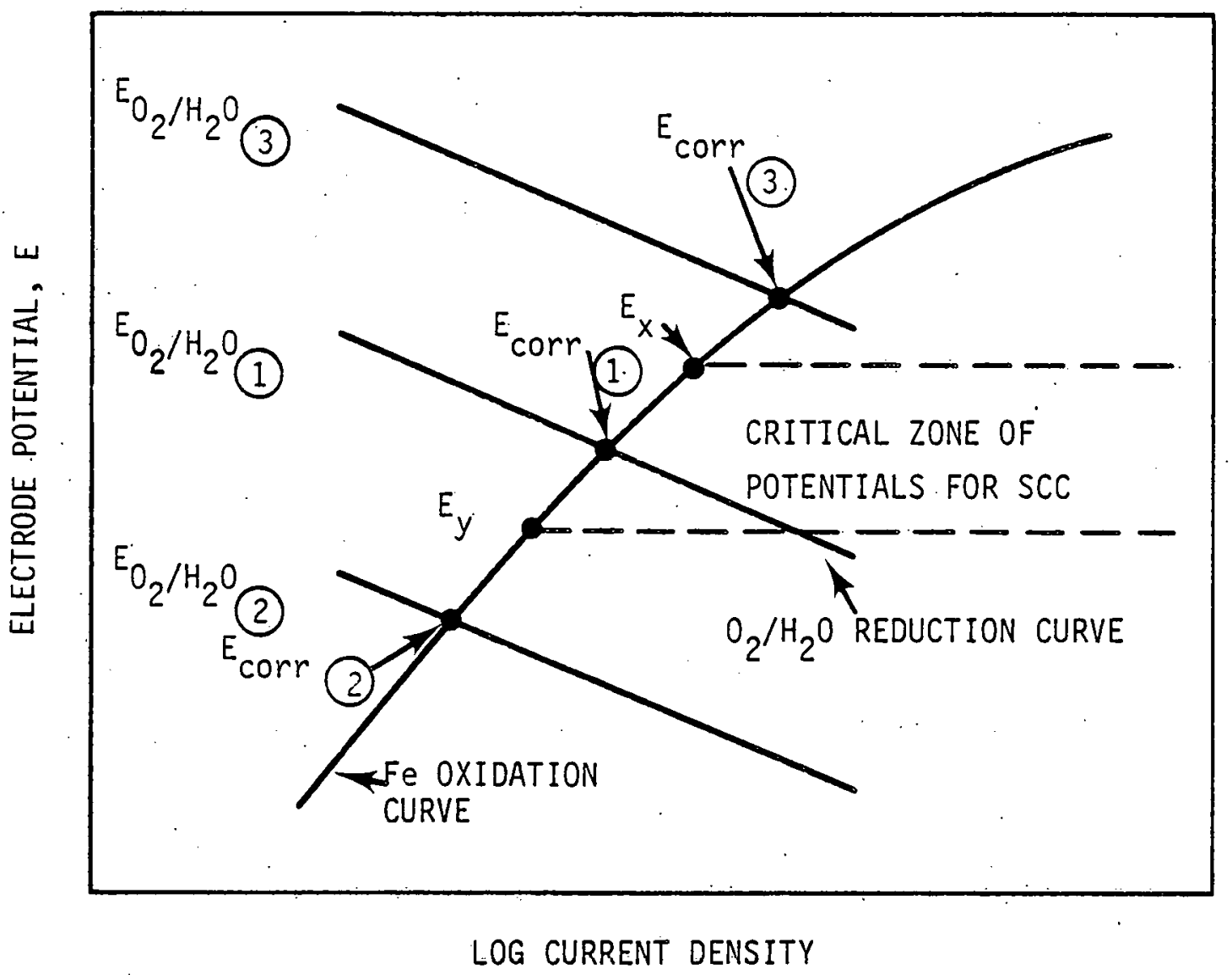

Figure 12. Schematic Polarization Curves Illustrating Effect of $\mathrm{O}_{2} / \mathrm{H}_{2} \mathrm{O}$ Equilibrium Potential on Corrosion Potential. (24) 
incidence of cracking appeared to parallel the detection of both oxygen and nitrogen. (17) Addition of only oxygen or only nitrogen to uncontaminated samples failed to produce cracking; both appear to be necessary to cause the problem. These tests also showed that carbon dioxide contamination is not essential for cracking, as was previously believed. (17)

In the work conducted at Southwest Research Institute, it was found that cracking susceptibility is a function of the concentrations of al1 the contaminants present. 0xygen was found to be the primary cracking agent when present in concentrations below about $300 \mathrm{ppm}$; at higher concentrations oxygen tended to produce inhibition. At concentrations below about $50 \mathrm{ppm}, \mathrm{CO}_{2}$ tended to inhibit stress-corrosion cracking, while at higher concentrations it tended to cause cracking. In solutions containing water and methane, nitrogen tended to inhibit cracking, but in solutions without methane and water, nitrogen tended to cause cracking. This is consistent with the U.S. Steel test results which were obtained from ammonias containing only oxygen and nitrogen. Methane was found to act as an inhibitor at all concentrations but large quantities were required to be effective. (24)

To investigate the possibility that stress-corrosion cracking of high-strength steels in liquid ammonia is due to hydrogen embrittlement, tests were conducted at U.S. Steel to establish the conditions under which hydrogen absorption takes place in air-contaminated ammonia. Hydrogen permeation was found to take place at an applied cathodic current density of $40 \mathrm{uA} / \mathrm{cm}^{2}$. (21) If hydrogen absorption were responsible for cracking under freely corroding conditions, then testing under conditions of known hydrogen permeation (i.e., with an applied cathodic current density of $40 \mathrm{uA} / \mathrm{cm}^{2}$ ) should cause premature cracking.

The results of tests to determine the influence of applied current (and therefore hydrogen permeation) on the stress-corrosion cracking susceptibility of A-517 Grade $F$ steel in air-contaminated liquid ammonia are shown in Figure $13 .^{(21)}$ This figure shows that $40 \mathrm{uA} / \mathrm{cm}^{2}$ applied cathodic current density produced no stress-corrosion cracking. At all cathodic currents, cracking was inhibited. At all anodic currents, 
cracking was stimulated (except in air-contaminated ammonia containing water), leading to the conclusion that the crack propagation mechanism involves an anodic dissolution step and cannot be attributed to hydrogen embrittlement.

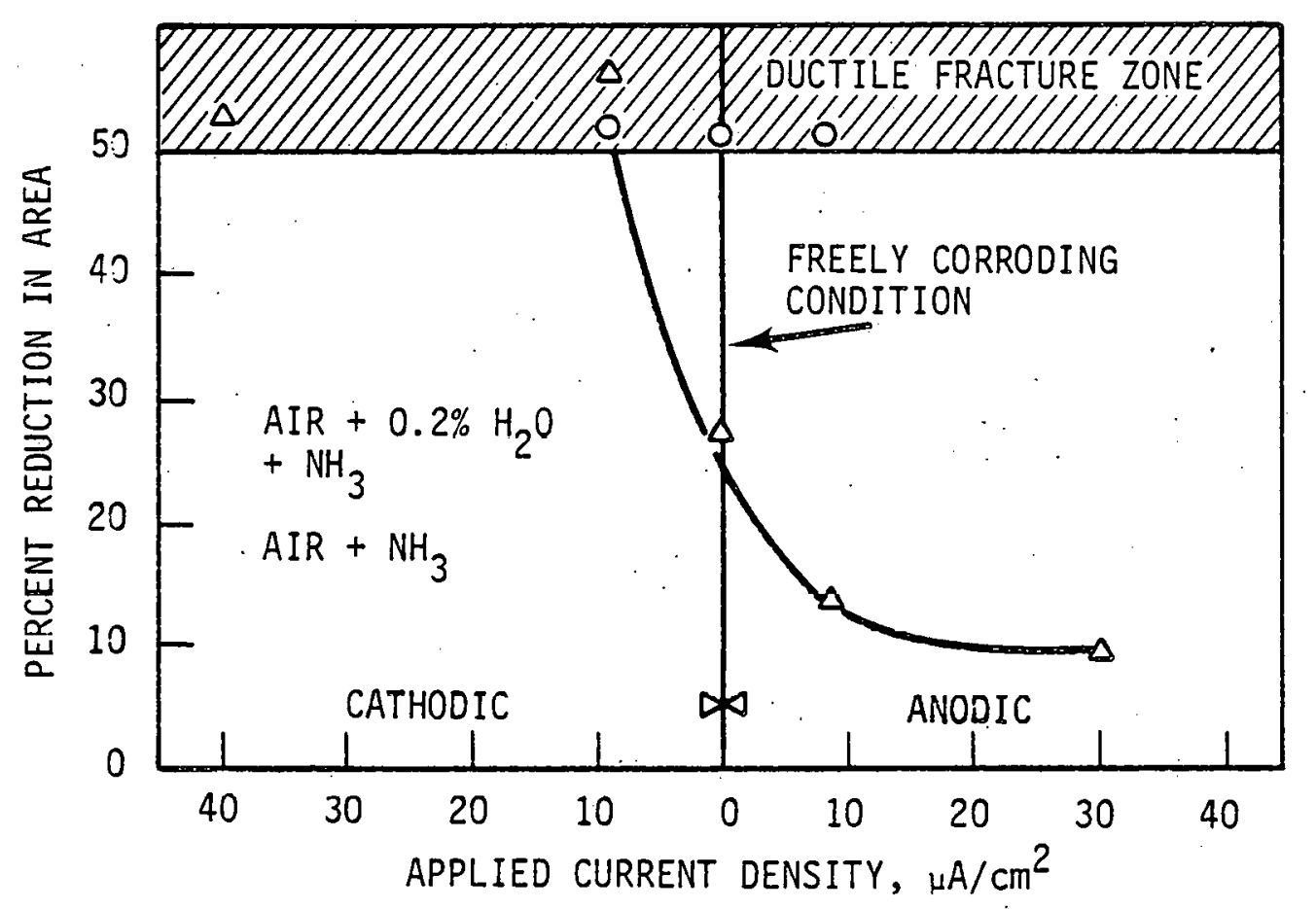

Figure 13. The Influence of Applied Current on the Stress Corrosion Cracking Susceptibility of A-517 Grade F Steel in Air Contaminated Liquid Ammonia. (21) 


\subsubsection{Mechanism of Cracking and Inhibition}

A proposed mechanism of stress-corrosion cracking of steels in air-contaminated ammonia was presented recently by Jones. This mechanism is outlined below and depicted in Figure 14.

1) In oxygen-contaminated ammonia an adsorbed film exists on the steel surface which maintains the potential at very noble values.

2) During straining after yield, breaks in the film produce film-free metal, which dissolves rapidly under the noble potential imposed by direct galvanic coupling to the filmed metal surface. In the absence of any other impurity, oxygen has a tendency to refilm the bare metal and to some degree inhibits the severity of stress-corrosion cracking, depending on the concentration and strain rate.

$$
\begin{aligned}
& \mathrm{O}_{2}+\mathrm{N}_{2} \\
& \hline O=O_{2} \\
& -=N_{2}
\end{aligned}
$$

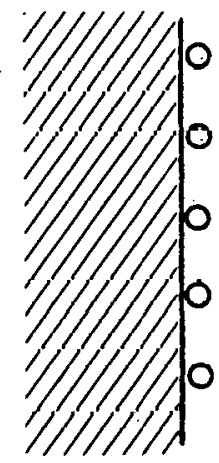

0. Film Formed Preferentially, Either From Air. or From Contaminated $\mathrm{NH}_{3}$.
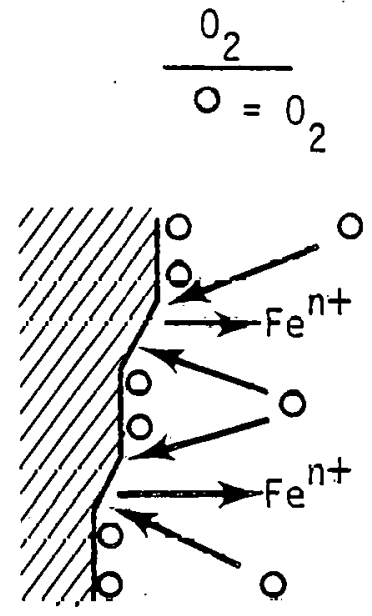

O2 Film Ruptured at Stip-Steps with $\mathrm{Fe}$ Dissolution. $0_{2}$ Trying to Repassivate.
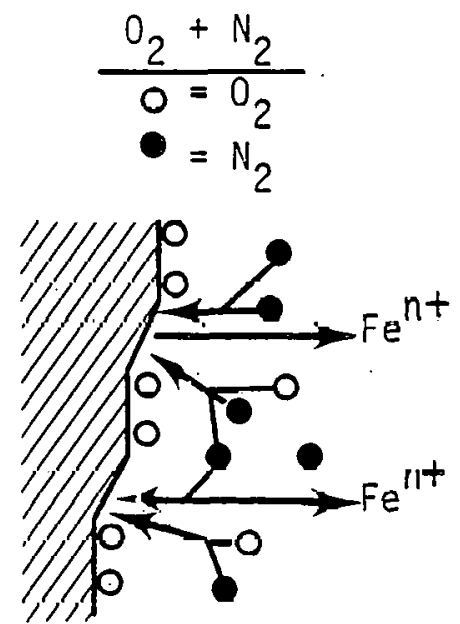

$\mathrm{O}_{2} \mathrm{Fi} 7 \mathrm{~m}$ Ruptured. $\mathrm{N}_{2}$ Competitive Absorption Maintains Active Dissolution at Slip Sites.

Figure 14. Proposed Mechanism of Stress-Corrosion Cracking of Steel in Anhydrous Ammonia Contaminated with Oxygen and Nitrogen. 
3) Nitrogen dissolved in the ammonia inhibits the refilming of the bare slip steps by a process of "competitive adsorption" with the oxygen and consequently increased the severity of stress-corrosion cracking through a process of adsorption rather than through a process of electrochemical origin. (25)

The mechanism of water inhibition is proposed to be rapid repassivation of bare metal formed at film rupture sites due to strain. $(23,25)$

\subsubsection{Corrosion Behvavior of Stainless Steel}

As indicated previously, stainless steels of all types are considered to be resistant to corrosion in liquid and gaseous anhydrous. ammonia. (4) The International Nickel Company, Inc. (INCO) states that, of the nickel-containing alloys, the austenitic stainless steels are most frequently employed in ammonia and ammonium hydroxide. Austenitic stainless steels exhibit good resistance to all concentrations of ammonia and ammonium hydroxide up to the boiling point. (26) General Atomic recommends austenitic 304L stainless steel for the ammonia condenser. tubing in a binary plant design for a gas turbine high-temperature gas reactor (HTGR). ${ }^{(27)}$ In this application, stainless steel condenser tubes would be compatible with both the external pressurized ammonia and the internal circulating coolant water.

\subsubsection{Use of Iron-Base Alloys in DCT Ammonia Cycles}

Structural carbon steels are suitable for use in the ammonia loop components, including the condenser shell and tubes, valves, storage tanks, heater feed pumps and condensate pumps. (27) However, the following recommendations should be adhered to if stress-corrrosion cracking is to be avoided:

1- The use of high yield strength steels should be avoided. Suitable steels for various ammonia loop components are given in Table 9 . 
2- The ammonia used in the cooling cycle should contain a minimum of $0.2 \%$ water as an inhibitor. Water additions should be made with deionized or distilled water or steam condensate. Ammonia in the cooling loop and storage tanks should be analyzed at least weekly for the prescribed water content.

3- Extreme care should be exercised to avoid air contamination of the amminia system. The system should be purged to an nxygen roncentration nt ul. $5 \% "$ with an inert. gas toliowed by ammonia vapor before being filled with anhydrous liquid ammonia.

4- Where practical, all components of the system should be post-weld heat treated or fabricated with steel that is hot-formed or stress-rel ieved.

5- Carbon steel components should be inspected periodically using nondestructive examination methods, particularly where components are not stress relieved or where high residual stresses are known to exist; e.g., at tube to tube sheet welds or where tubes are rolled into tube sheets.

The austenitic stainless steels are suitable for use in all ammonia loop components; however, their use may be tempered by their higher cost (see Table 2). 
Table 9. Suitable Steels for Various Components in the DCT Ammonia Loop

\begin{tabular}{lll}
\multicolumn{1}{c}{ Component } & Steel & Yield Strength \\
$\begin{array}{l}\text { Condenser-Reboiler and } \\
\text { Heat Exchanger }\end{array}$ & ASTM A-179 & $241 \mathrm{MPa}$ (35 ksi) \\
$\begin{array}{l}\text { Condenser Shell and } \\
\text { Headers }\end{array}$ & ASTM A-214 & $241 \mathrm{MPa}$ (35 ksi) \\
Piping & ASTM A-285 Grade C & $207 \mathrm{MPa}(30 \mathrm{ksi})$ \\
& ASTM A-53 Grade B & $241 \mathrm{MPa}$ (35 ksi) \\
Flanges and Fittings & ASTM A-106 Grade B & $241 \mathrm{MPa}(35 \mathrm{ksi})$ \\
& ASTM A-105 & $248 \mathrm{MPa}(36 \mathrm{ksi})$
\end{tabular}

5. EFFECT OF AMMONIA LEAKAGE ON CONTROL OF CONDENSATE CHEMISTRY

Assuming complete mixing, the added ammonia concentration in the steam condensate due to leakage from the condenser-reboiler can be approximated using the general equation

$$
\mathrm{NH}_{3} \text { in Condensate }(\mathrm{ppm})=\frac{\text { Leak Rate } \times 10^{6}}{\text { Condensate Flow Rate }} .
$$

Using leak rates and condensate flow rates in $\mathrm{kg} / \mathrm{hr}$, the resulting $\mathrm{NH}_{3}$ concentrations are in $\mathrm{mg} / \mathrm{kg}(\mathrm{ppm})$. From these values the condensate $\mathrm{pH}$ can be calculated from

$$
\mathrm{pH}=11.6252+1 / 2 \log \frac{\mathrm{ppm} \mathrm{NH}^{*}}{17,000} 3^{*} .
$$

* Derivation of this equation is given in Appendix 7.2. 
A plot of condensate $\mathrm{pH}$ versus ammonia leak rate is given in Figure 15 for four different condensate flow rates. Typical condensate flow rate for a 1000 MWe pressurized water reactor (PWR) is on the order of 5.5 $6.0 \mathrm{million} \mathrm{kg} / \mathrm{hr}$; fossil-fuel boilers of similar size will produce a condensate flow rate of about $3.5-4.0 \mathrm{million} \mathrm{kg} / \mathrm{hr}$.

High pressure fossil-fuel boilers utilize all volatile treatment, and since the latter part of 1974 the use of all volatile (zero solids) treatment has been specified by most PWR steam generator vendors. Ammonia is used to control the $\mathrm{pH}$ in both cases. The recommended $\mathrm{pH}$ range of feedwater for both high-pressure boijers and steam generators is $9.2-9.5$ (27) $^{(27}$ th corresponds to about $1.0 \mathrm{ppm}$ ammonia. In the uni ikely event of an ammonia leak into the condensate on the order of $100 \mathrm{~kg} / \mathrm{hr}$, condensate $\mathrm{pH}$ would increase to about 10.1-10.2 (see Fiqure 7). The conductivity of the condensate would increase from about $5 \mu \mathrm{mho} / \mathrm{cm}$ to about $30 \mu \mathrm{mho} / \mathrm{cm} .{ }^{(28)}$ Thus the leak could be readily detected; even if it were not repaired in a matter of hours or even days no damage to carbon steel, Inconel 600 or other materials in the condensate/feedwater circuit would be expected, provided that the use of copper-base alloys in feedwater heaterers was avoided.

Overloading of cation-exchange resins in condensate polishers would not be a problem since ammoniated mixed-bed demineralizers are now widely used in systems using all-volatile treatment. (30)

In boiling water reactors (BWR's), ammonia can be used to suppress radiolytic oxygen production by reacting with the $\mathrm{OH}$ radicals produced by water radiolysis. Ammonia is being used successfully for this purpose in the CANDU-BLW pressure-tube reactor at Gentilly, Quebec. (31) However, the use of ammonia to reduce oxygen concentration in the coolant of pressure-vessel BWR's of the type used in the United States is not as promising, since for 1000-MWe reactor the ammonia decomposition rate due to radiolysis is in the range of 60 to $480 \mathrm{~kg} / \mathrm{hr}$ or even higher. This would indicate that ammonia leaks into BWR condensate would be of 


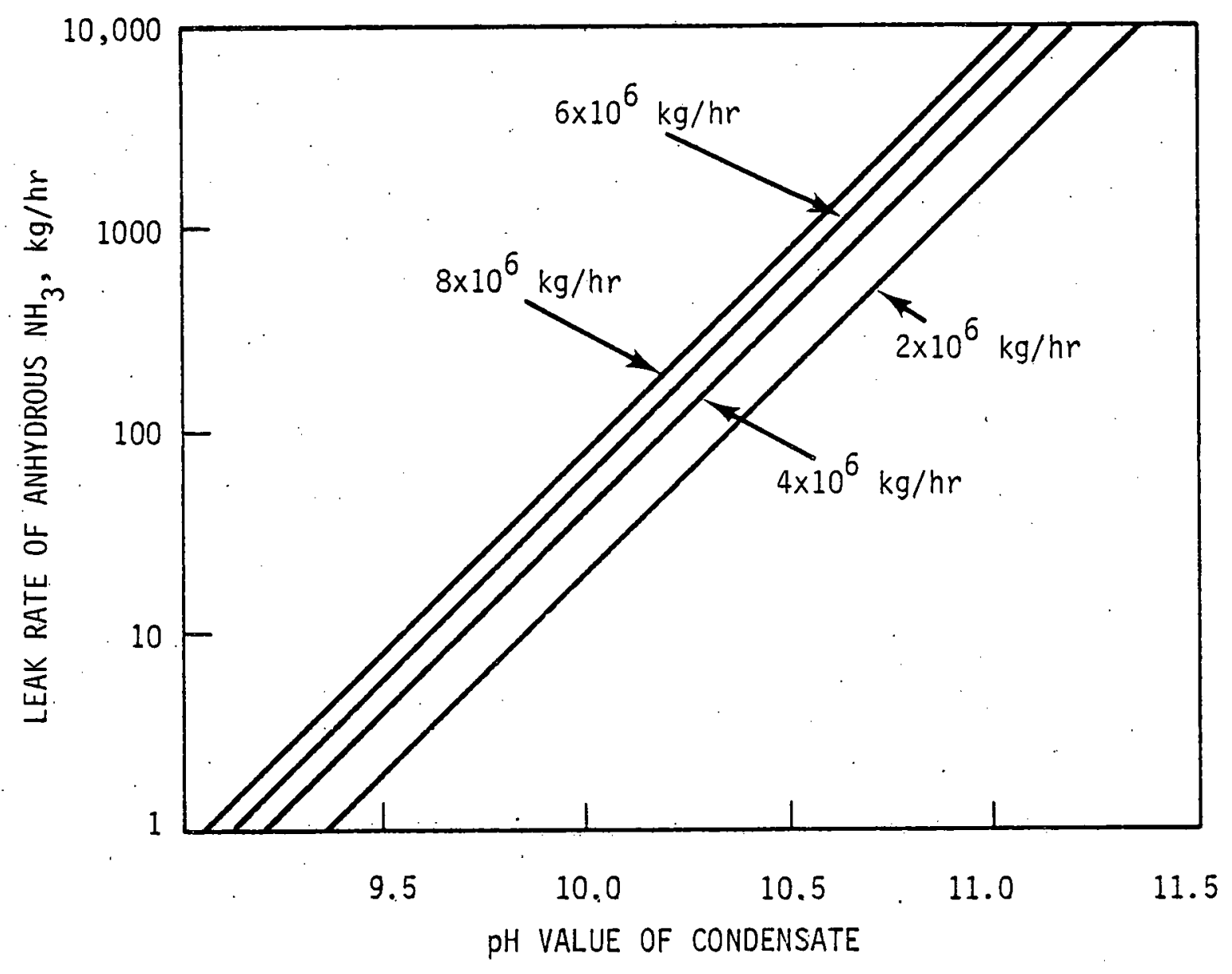

Figure 15. Condensate $\mathrm{pH}$ as a Function of Ammonia Leak Rate at Various Condensate Fiow Rates, Assuming Complete Mixing. 
even less consequence than in the case of fossil-fuel boilers and PWR steam generators. The only adverse effect of an ammonia leak through the condenser-reboiler would be the increased amount of noncondensable gas production; each $\mathrm{kg}$ of ammonia that is decomposed radiolytically gives 2600 liters of hydrogen and nitrogen at STP.

Overall it appears that leakage of ammonia through the condenserreboiler into the steam condensate will not be a problem of major concern for several reasons:

1) The condenser-reboiler can be constructed of materials which are resistant to corrosion in ammonia, thus reduring the prohability of leaks:

2) In fossil-fuel plants and PWR's, leaks of ammnnia into the condensate can be easily detected and will not cause accelerated corrosion of materials in the condensate/feedwater cycle.

3) In BWR's, ammonia is rapidly decomposed radiolytically; the only problem caused by an ammonia leak would be an increased volume of noncondensable gases in the condenser. 


\section{ACKNOWLEDGEMENTS}

Companies from which data was obtained include U.S. Steel Corporation, Clairton Works, Clairton, PA; Southwest Research Institute, San Antonio, TX; E. I. DuPont Company, Victoria, TX; and Pullman Kellogg, Houston, TX. Valuable information has also been received from Aluminum Company of America, Alcoa Center, PA, the Reynolds Metals Company; Richmond, VA, the International Institute of Ammonia Refrigeration, Chicago, IL and U.S. Steel Corporation Research Laboratory, Monroeville, PA. The assistance of these companies in defining the corrosion performance of dry cooling tower materials in ammonia is gratefully acknowledged.

Appreciation is also expressed to Dr. R. T. Allemann, Dr. R. L. Dillon, Dr. A. B. Johnson, Jr., and Dr. B. M. Johnson for their review of the manuscript and helpful suggestions. 


\section{APPENDICES}

7.1 Design Parameters of Industrial Equipment Handling Ammonia

\subsubsection{Ammonia Condensers}

$$
\text { Company A }
$$

Company B

Shell

$\begin{array}{lcl}\text { Material } & \begin{array}{l}\text { A-285 Grade } C \\ \text { Carbon Steel }\end{array} & \begin{array}{l}\text { A-212 Grade B } \\ \text { Carbon Steel }\end{array} \\ \text { Thickness } & - & 12.70 \mathrm{~mm}(0.50 \mathrm{in} .) \\ \text { Corrosion A1lowance } & 3.2 \mathrm{~mm}(0.125 \mathrm{in} .) & 3.2 \mathrm{~mm}(0.125 \mathrm{in} .) \\ \text { Diameter } & 111.8 \mathrm{~cm}(3.67 \mathrm{ft}) & 86.36 \mathrm{~cm}(2.83 \mathrm{ft}) \\ \text { Length } & 6.1 \mathrm{~m}(20 \mathrm{ft}) & 7.3 \mathrm{~m}(24 \mathrm{ft}) \\ \text { Design Pressure } & 2.1 \mathrm{MPa}(300 \mathrm{psig}) & 1.6 \mathrm{MPa}(230 \mathrm{psig}) \\ \text { Design Temperature } & 177^{\circ} \mathrm{C}\left(350^{\circ} \mathrm{F}\right) & 38^{\circ} \mathrm{C}\left(100^{\circ} \mathrm{F}\right)\end{array}$

Tube Sheets

Material

Thickness

A-285 Grade C Carbon Steel.

Tubes

Material

Outside Diameter

Wa 11 Thickness

Length

Number

Maximum Design

Pressure

Maximum Design

Pressure

Operating Temperature
A-214 Carbon Steel.

$1.9 \mathrm{~cm}$ (0.75 in.)

$2.4 \mathrm{~mm}(0.095 \mathrm{in.})$

$6.1 \mathrm{~m}(20 \mathrm{ft})$

1600

Operating - $1.5 \mathrm{MPa}$

(218 psig)

$102^{\circ} \mathrm{C}\left(215^{\circ} \mathrm{F}\right)-$ IN

$39^{\circ} \mathrm{C}\left(102^{\circ} \mathrm{F}\right)-$ OUT
A-105 Carbon Steel

$13.65 \mathrm{~cm}$ (5.375 in.)

A-179 Carbon Steel

$15.875 \mathrm{~mm}$ (0.625 in.)

$3.05 \mathrm{~mm}(0.120$ in.)

$7.3 \mathrm{~m}(24 \mathrm{ft})$

222

$28.96 \mathrm{MPa}$ (4200 psig).

$66^{\circ} \mathrm{C}\left(150^{\circ} \mathrm{F}\right)$

$43^{\circ} \mathrm{C}\left(110^{\circ} \mathrm{F}\right)-$ IN

$18^{\circ} \mathrm{C}\left(64^{\circ} \mathrm{F}\right)$ - OUT 


\subsubsection{Primary Ammonia Coolers (Fin-Fan)}

Tubes

Material

Outside Diameter

Wall Thickness

Length

Number

Operating Pressure

Fins

Material
Height
Type
External Surface Area
eaders

Material

Corrosion Allowance

Temperature

Ammonia IN

Ammonia OUT

Air IN

Air OUT

Heat Exchange
Company B

A-210 Carbon Steel

$25.4 \mathrm{~mm}$ (1.0 in.)

$3.76 \mathrm{~mm}(0.148$ in. $)$

$9.1 \mathrm{~m}(30 \mathrm{ft})$

193, 4 rows deep

$25.68 \mathrm{MPa}$ (3725 psig)

A7uminum

$15.875 \mathrm{~mm}(0.625 \mathrm{in.})$

Extruded, 9 per in. $5342 \mathrm{~m}^{2}\left(57,500 \mathrm{ft}^{2}\right)$

A-285 Grade C Carbon Stee 1

$3.175 \mathrm{~mm}$ (0.125 in.)

$127^{\circ} \mathrm{C}\left(261^{\circ} \mathrm{F}\right)$ - Vapor

$43^{\circ} \mathrm{C}\left(110^{\circ} \mathrm{F}\right)$ - Vapor

$38^{\circ} \mathrm{C}\left(100^{\circ} \mathrm{F}\right)$ - Design

$66^{\circ} \mathrm{C}\left(151^{\circ} \mathrm{F}\right)=$ Design

$3.87 \mathrm{MW}\left(13.23 \times 10^{6} \mathrm{BTU} / \mathrm{hr}\right)$ 


\subsection{Derivation of Formula Relating Solution $\mathrm{pH}$ to Ammonia Concentration}

The equation: $\mathrm{pH}=11.6252+1 / 2 \log \frac{\mathrm{ppm} \mathrm{NH}}{17,000} 3-$ is derived as follows: Butler (32) gives the ionization constant of ammonia as $1.78 \times 10^{-5}$. Thus,

$$
\left[\mathrm{NH}_{4}^{+}\right]\left[\mathrm{OH}^{-}\right]=\left(1.78 \times 10^{-5}\right)\left[\mathrm{NH}_{3}\right]
$$

The ionization of water is governed by

$$
\left[\mathrm{H}^{+}\right]\left[\mathrm{OH}^{-}\right]=1.00 \times 10^{-14}
$$

Thus,

$$
\left[\mathrm{OH}^{-}\right]=\left(1.00 \times 10^{-14}\right) /\left[\mathrm{H}^{+}\right]
$$

Balancing charges gives

$$
\left[\mathrm{H}^{+}\right]+\left[\mathrm{NH}_{4}^{+}\right]=\left[\mathrm{OH}^{-}\right]
$$

Since the solution is basic, we can neglect $\left[\mathrm{H}^{+}\right]$compared to $\left[\mathrm{OH}^{-}\right]$ in Equation (3), and

$$
\left[\mathrm{NH}_{4}^{+}\right]=\left[\mathrm{OH}^{-}\right]
$$

Substituting (2a) and (3a) into (1), gives

$$
\begin{aligned}
& \frac{\left(1.00 \times 10^{-14}\right)}{\left[\mathrm{H}^{+}\right]}=\left(1.78 \times 10^{-5}\right)\left[\mathrm{NH}_{3}\right] ; \\
& {\left[\mathrm{H}^{+}\right]^{2}=\frac{\left(1.00 \times 10^{-28}\right)}{\left(1.78 \times 10^{-5}\right)\left[\mathrm{NH}_{3}\right]} ;} \\
& 2 \log \left[\mathrm{H}^{+}\right]=-2.3 .25-\log \left[\mathrm{NH}_{3}\right] ; \\
& \mathrm{pH}=11.6252+1 / 2 \log \left[\mathrm{NH}_{3}\right] .
\end{aligned}
$$

Since

$$
\left[\mathrm{NH}_{3}\right]=\mathrm{ppm} \mathrm{NH} \mathrm{H}_{3} / 17,000
$$

then,

$$
\mathrm{pH}=11.6252+1 / 2 \log \frac{\mathrm{ppm} \mathrm{NH}}{17,000} .
$$




\section{REFERENCES}

1. R. G. Seth and W. Steigelmann, "Binary-Cycle Power Plants Using Dry Cooling Systems. Part 1 - Technical and Economic Evaluation," FC3023, (1972).

2. R. C. Weast and S. M. Selby, Ed., Handbook of Chemistry and Physics, 48th Edition, Chemical Rubber Co., Cleveland, Ohio, p. E-14, $(1967-68)$.

3. H. J. MacIntire and F. W. Hutchinson, Refrigeration Engineering, 2nd Edition, John Wiley \& Sons, New York, (1950).

4. H. H. Uhlig, The Corrosion Handbook, John Wiley \& Sons, New York, $.799(1948)$.

5. Anonymous, "Comparison of Materials - Prices of Materials, "Materials Engineering, 82(4), 22 (Sept. 1975).

6. J. R. Willard and R. B. Mears, "Aluminum in Refrigerating Equipment," J. Amer. Soc. Refrig. Eng., 40, 381 (Dec. 1940).

7. K. L. Tseitlin, Y. I. Sorokin, A. A. Balashova, S. M. Babitskaya, Y. S. Levin, A. T. Konyusheuko, R. V. Golovkin and B. S. Ladyzhinskii, "High-Temperature Corrosion of Metals in Gaseous Ammonia," Zashchita Metalov, 6, 451 (1970).

8. R. A. Bonewitz, "Corrosion of Aluminum in Ammonia-Water Mixtures," Alcoa Laboratories Report (to be published).

9. D. A. Jones and B. E. Wilde, "Corrosion Performance of Some Metals and Alloys in Liquid Ammonia." (To be published in Corrosion).

10. A. B. Johnson, Jr., D. R. Pratt and G. E. Zima, "Survey of Materials and Corrosion Performance in Dry Cooling Applications," BNWL-1958 (March 1976).

11. J. C. Hines, "The Behavior of Aluminum in Ammonical Solutions," Alluminio, $\underline{\underline{34}}(5) 23$, (1965).

12. R. A. Bonewitz, Alcoa Technical Center, Alcoa Center, PA, personal communication.

13. A. W. Loginow and E. H. Phelps., "Stress-Corrosion Cracking of Steels in Agricultural Ammonia," Corrosion, 18(8), $290 \mathrm{t}$ (1962).

14. W. P. LeDet, Division Superintendent, Victoria Plant, E. I. duPont Company, Victoria, Texas, personal communication. 
15. D. G. Wilson, General Superintendent, Clairton Works, U. S. Steel Corporation, Clairton, Pennsylvania, personal communication.

16. T. J. Dawson, "Behavior of Welded Pressure Vessels in Agricultural Ammonia Service," Welding Journal, 35, 568, (June 1956).

17. E. H. Phelps, "Causes of Stress-Corrosion Cracking of Steel in Ammonia," Ammonia Plant Safety, 16, 32 (1974).

18. L. Medard, "Rupture of an Ammonia Road Tanker," Ammonia Plant Safety, 12, 17 (1970).

19. H. Lonsdale, "Ammonia Tank Failure - South Africa," Ammonia Plant Safety, 17, 126 (1975).

20. E. A. Olsen, "The New Rules for Ammonia Highway Tank Transports," Ammonia. Plant Safety, 11, 46 (1969).

21. D. C. Deegan and B. E. Wilde, "Stress-Corrosion Cracking Behavior of ASTM A-517 Grade F Stee 1 in Liquid Ammonia Environments," Corrosion, $\underline{29}(8), 310(1973)$.

22. C. D. Kim, B. E. Wilde and E. H. Phelps, "Stress-Corrosion Cracking of Line-Pipe Steels in Anhydrous Ammonia, Corrosion, 31(7), 255 (1975).

23. J. H. Gross, U. S. Steel Corporation Research Laboratory, Monroeville, Pennsylvania, personal communication.

24. F. F. Lyle, Jr., "A Study of Stress Corroston Phennment Resultiting from Transportation of Anhydrous Ammonis in Quenched-and-Tempered Steel Cargo Tanks," Report No. DOT-FH-11-8568, prepared for Department of Transportation by Southwest Research Institute (February 1976).

25. D. A. Jones, C. D. Kim and B. E. Wilde, "The Ëlectrochemistry and Mechanism of Stress Corrosion Cracking of Constructional Steels in Liquid Ammonia." (to be published in Corrosion).

26. Anonymous, "Corrosion Resistance of Nickel and Nickel-Containing Alloys in Caustic Soda and Other Alkalles," INCO Technical Publication, CEB-2, 20 (1973).

27. T. W. Schoene, E. O. Whnkler and P. Fortescue, "The Gas Turbine HTGR Plant - Economical Dry Cooling or a Wet-Cooled High Efficiency

Binary Configuration," Proc. Amer. Power Conf. (1975).

28. Anonymous, Steam - Its Generation and Use, 38th Edition, The Babcock and Wilcox Co., New York, (1972). 
29. P. D. Stevens-Guille and M. G. Hare, "Steam Generator Tube Failures: World Experience in Water-Cooled Nuclear Power Reactors in 1973," AECL-5013 (January 1975).

30. G. J. Crits and W. H. Zahn, "Ammoniated Mixed-Bed Demineralizer Experiences in Condensable Purification," Proc. Amer. Power Conf., 30, 917 (1968).

31. J. E. LeSurf and G. M. Allison, "Ammonia Suppresses Oxygen Production in Boiling Water Reactors," Trans. Amer. Nucl. Soc., 22, 550 (1975).

32. J. N. Butler, Solubility and $\mathrm{pH}$ Calculations, Addison-Wesley Publishing. Company, Inc., Massachusetts, p. 55, 1964. 
DISTRIBUTION

No. of

Copies

OFFSITE

A. A. Churm

ERDA Chicago Patent Group

U.S. ERDA

9800 So. Cass Ave.

Argonne, IL 60439

U.S. ERDA Office of Assistant General Counsel for Patents Washington, DC 20545

165 ERDA Technical Information Center

4 W. F. Savage

Advanced Concepts

Evaluation Branch

ERDA Division of Nuclear Research and Application

Washington, DC 20545

G. W. Cunningham

Acting Deputy Director for Technology

Division of Nuclear Research and Application

U.S. ERDA

Washington, DC 20545

A. J. Pressesky

Acting Assistant Director for Technology

Division of Nuclear Research and Application

U.S. ERDA

Washington, D.C. 20545
No. of

Copies
G. A. Newby

Acting Director

Division of Nuclear Research and Application

U.S. ERDA

Washington, DC 20545

D. H. Groelsema

Chief, Engineering and Components Development Branch

ERDA Division of Nuclear Research and Application

Washington, DC 20545

T. Beresovski

Chief, Advanced Concepts

Evaluation Branch

ERDA Division of Nuclear. Research and Application

Washington, DC 20545

B. R. Dickey

A1l ied Chemical Company

550 2nd St.

Idaho Falls, ID 83401

J. S. Joyce

Al1 is-Chalmers Power Systems, Inc.

1135 So. 70th St.

West Allis, WI 53214

E. T. Wanderer

Aluminum Company of America

Alcoa Technical Center

Alcoa Center, OH. 45069

H. J. Janzon

American Electric Power

2 Broadway

New York, NY 10004 
T. Woods

Arizona Public Service Co.

2121 W. Cheryl Dr.

Phoenix, AZ 85021

M. W. Peterson

Babcock \& Wilcox

Fossil Power Division

20 So. Van Buren

Barberton, OH 44203

E. Schinner

Baltimore Aircoil Co., Inc.

P.0. Büx $73 \hat{z 2}$

Baltimore, MD 21227.

G. C. Crepel

Baltimore Gas \& Electric Co. Gas \& Electric BIdg.

Baltimore, MD 21203

J. P. Budliger

Battele-Geneva

7 Route De Mrizi

1227 Geneva, SWITZERLAND

K. Simhan

Battelle Institute eV.

6000 Frankfurt/Main 90

Postfach 900160

GERMANY

P. Leung

Bechtel Corporation

P.0. Box 60860

Terminal Annex

Los Angeles, CA 90060

G. R. Retti

Bechtel Corporation

P.0. Box 3965

San Francisco, CA 94119

W. J. Westre

Black Hills Power and Light Co.

P.0. Box 1400

Rapid City, SD 57701
J. Sell

Carolina Power \& Light Co.

336 Fayettesville St.

Raleigh; NC 27602

J. Morse

Catalytic Construction Corp.

P.0. Box 11402

Charlotte, NC 28029

R. H. Holyoak

Commonwealth Edison

One First Plaza

ก.0. Box 767

Chicago, IL 60690

C. L. Newman

Consolidated Edison lo. of New York, Inc.

4 Irving Place

New York, NY 10003

P. Sporn

Consultant Engineer

74 Trinity P1., Suite 511

New York, NY 10006

F. K. Moore

Corriell University

Ithaca, NY 14850

R. C. Haberski

Curtiss Wright Corp.

One Passaic St.

Wood Ridge, NJ 07075

S. K. Blackley

Duke Power Co.

P. 0. Box 2178

Charlotte, NC 28201

J. K. Swindt

Ecodyne Cooling Products Co.

San Rosa, CA 95403 
W. P. Ledet

Division Superintendent

E. I. DuPont Company

0ld Bloomington Road

Victoria, TX 77901

J. Maulbetsch

Electric Power Research Institute 3412 Hillview Ave.

P.0. Box 10412

Palo Alto, CA 94304

L. Geller

Empire State Electric Energy Research Corp.

1250 Broadway

New York, NY 10001

E. C. Smith

Hudson Products

6855 Horwin Dr.

Houston, TX 77036

C. Rocco

Ital impianti - Societa

Italiana Impianti p.a.

Piazza, Piccapietra 9

18121, Genoa, ITALY

W. V. Richards, President

International Institute oa Ammonia Refrigeration

111 East Wacker Drive.

Chicago, IL 60601

J. F. Mulloy

Los Angeles Department of Water and Power

111 N. Hope St.

Los Angeles, CA 90012

R. J. Meyer

Louisiana Power \& Light Co.

142 Delaronde St.

New Orleans, LA 7-174
R. Landon

Marley Co.

5800 Fox Ridge Dr.

Mission, KS 66202

L. R. GTicksman

Massachusetts Institute of Technology

77 Massachusetts Ave.

Cambridge, MA 02139

W. G. Hoydysn

New York University

University Heights

New York, NY 10453

F. H. Rainwater

Environmental Protection Agency

Pacific Northwest Water Laboratory

200 S.W. 35th St.

Corvallis, OR. 97330

A. M. Rubin

Frankl in Institute

Twentieth \& Parkway

Philadelphia, PA 19103

B. Davis

GEA Airexchangers, Inc.

46 Worthington Dr.

Maryland Helghts, MU 63043

D. A. Nelson

General Atomics

P.0. Box 81.608

San Diego, CA 92138

E. H. Miller.

General Electric Co.

Large Steam Turbine Division

300 Nott St.

Schenectady, NY 12301 
No. of

Copies

J. F. Sebald

Gilbert Associates, Inc.

525 Lancaster Ave.

Reading, PA 19603

J. E. Taboric

Heat Transfer Research Inc.

1000 S. Fremont Ave.

Alhalibra, CA 91802

M. W. Larinoff

Hudson Products

6855 Horwin Dr.

Houston, TX 77036

W. Kals

Niagara Blower

405 Lexington Ave.

New! York, NY 10017

R. H. Meyer

Northeast Uitlities

P.0. Box 270

Hartford, CT 06101

C. E. Wicks

Dept. of Chemical Engineering

Oregon State University

Corvalitis, OR 97330

L. P. Davis

Dept. Of Mechanical

Engineering

Oregon State University

Corvallis, OR 97330

F. F. Mautz

Pacific Gas \& Electric

77 Beale St.

San Francisco, CA 94106

P. G. Humphries

Pacific Power \& Light Co.

Public Service Bldg.

Portland, OR 97204
No. of

Copies

T. Rozenman

PFR Engineering Systems

$14: 17$ S. Georgia St.

Los Angeles, CA 90015

Prof. Ing. Carlo Roma

Piazza delle Muse 8

Rome, ITALY

A. C. Smith

Power Generation Cooling Sys tems

4714 - 52nd St. S.

Seattle, WA 98118

R. F. Walker

Public Service of Colorado

5900 E. 3yth Ave.

Denver, CO 80207

E. D. Kist

Public Service of New Mexico

Corporate Planning Dept.

Albuquerque, NM 87103

L. J. Buividas

Manager, Inorganic Chemicals Division

Pullman Kellogg Company

1300 Three Greenway Plaza Fast

Houston, TX 77046

G. E. Collins

Research Cottrell

Hamon Cooling Tower Division

Box 750

Bound Brook, NY 08805

R. I. Lindberg

Director, Corrosion Engineering

Reynolds Metals Company

Fourth \& Canal Streets

Richmond, VA 23219 
No. of

Copies

B. Caruthers

Reynolds Metals Co.

Reynolds Metallurgical

Research Laboratory

Richmond, VA 23261

J. P. Rossie

R. W. Beck \& Associates

400 Prudential Plaza

Denver, CO 80202

R. G. Lacy

San Diego Gas \& Electric

101 Ash St.

San Diego, CA 92107

R. L. Skone

Seattle City Light

1015 Third Ave.

Seattle, WA 98104

J. Rasband

Southern California Edison

2244 Walnut Grove Ave.

Rosemead, CA 91770

F. F. Lyle

Senior Corrosion Engineer

Southwest Research Institute

P.0. Drawer 28510

San Antonio, TX 78284

D. H. Guild

Stone \& Webster Engineering

Corp.

225 Frankl in ST.

Boston, MA 02107

J. Y. Parce

Stearns and Rogers

$700 \mathrm{~S}$. Ash St.

Denver, CO 80222

H. T. Wilson

Tampa Electric Co.

P.O. Box 111

Tampa, FL 33601
No. of

Copies

W. Keel

Texas Electric Service Co.

115 W. Seventh St.

Fort Worth, TX 76102

J. Bartz

Senior Engineer

Union Carbide Corporation, Linde Division

61 East Park Drive

Tonowanda, NY 14150

G. J. Kidd

Union Carbide Corp.

ORGDP - K-25

P.0. Box D

Oak Ridge, TN 37803

G. A. Engelson

United Engineers \& Constructors

IVB BI dg.

1700 Market St.

Philadelphia, PA 19105

R. L.Walls

General Superintendent

U.S. Steel Corporation,

Clairton Works

400 State Street

Clairton, PA 15025

J. H. Gross

Director - Research

U.S. Steel Corporation

Research Laboratory

125 Jamison Lane

Monroeville, PA 15146

J. F: Kennedy

University of Iowa

Hydraulic Research Institute

Iowa City, IA 52240

J. H. Hutchinson

Utah Power \& Light

1407 W. N. Temple

Salt Lake City, ITT 84103 
No. of

Copies

S. Ragone

Virginia Electric \& Power Co. 700 E. Franklin St.

Richmond, VA 2326 ?

G. H. Soule

West Associates

Sierra Pacific Power Co.

100 E. Moana Lane

Reno, NV 89510

K. A. Oleson

Westinghouse Electric Corp.

Steam Turbines Division

Lester Branch

Box 9175

Philadelphia, PA 19113

G. J. Silvestri

Westinghouse Electric Corp.

Steam Turbines Division

Lester Branch

Box 9175

Philadelphia, PA 19113

\section{ONSITE}

ERDA Richland Operation Office Program Division

B. J. Melton

Westinghouse Hanford Company

Handord Engineering Development

Laboratory

J. Flatcher
No. of

Copies

88 Battelle-Northwest

R. T. Allemann

T. W. Ambrose

P. A. Ard

J. W. Currie

D. E. Deonigi

J. G. DeSteese

R. L. Dillon

D. W. Dragnich

D. W. Faletti

J. W. Finnigan

B. C. Fryer

C. H. Henager

A. B. Johnson

W. S. Kelly

R. S. Kemper

C. J. Knoll

W. V. Loscutoff

R. P. Marshal1

D. E. Olesen

Y. Onishi

L. T. Pedersen

D. R. Pratt (20)

H. C. Riches

J. B. Schuette

G. C. Smith

J. S. Stoakes

A. M. Sutey

D. S. Trent:

M. Vagins

R. A. Walter

R. L. Watts

R. D. Widrig

R. K. Woodriff

G. E. Zima

File - B. M. Johnson (30)

Technical Information (3)

Technical Publications (2) 